\title{
Design, Synthesis, and Biological Evaluation of Novel Indoles Targeting the Influenza PB2 Cap Binding Region
}

David C. McGowan, $,^{\dagger},{ }^{*}$ Wendy Balemans, ${ }^{\dagger}$ Werner Embrechts, ${ }^{\dagger}$ Magali Motte, ${ }^{\S}$ Jeremy . Keown, ${ }^{\Phi}$ Christophe Buyck, ${ }^{\dagger}$ Jordi Corbera, ${ }^{+}$Mario Funes, ${ }^{\dagger}$ Laura Moreno, ${ }^{+}$Ludwig Cooymans, ${ }^{\dagger}$ Abdellah Tahri, ${ }^{\dagger}$ Julien Eymard, ${ }^{\gamma}$ Bart Stoops,${ }^{\dagger}$ Rudy Strijbos, ${ }^{\circ}$ Joke Van den Berg, ${ }^{\dagger}$ Ervin Fodor, ${ }^{\infty}$ Jonathan M. Grimes, ${ }^{\phi}$, Anil Koul,${ }^{\dagger}$ Tim H.M. Jonckers, ${ }^{\dagger}$ Pierre Raboisson, ${ }^{\dagger}$ Jérôme Guillemont ${ }^{\S}$

${ }^{\dagger}$ Janssen Pharmaceutica, N.V. Turnhoutseweg 30, 2340 Beerse, Belgium SJanssen-Cilag, Campus de Maigremont BP615, F-27106 Val de Reuil Cedex, France

${ }^{\gamma}$ Novalix (site Janssen-Cilag), Campus de Maigremont BP615, F-27106 Val de Reuil Cedex, France $\phi$ Division of Structural Biology, Henry Wellcome Building for Genomic Medicine, University of Oxford, Oxford OX3 7BN, UK

${ }^{\infty}$ Sir William Dunn School of Pathology, University of Oxford, South Parks Rd, Oxford OX1 3RE, UK

${ }^{\diamond}$ Diamond Light Source, Harwell Science and Innovation Campus, Didcot, OX11 ODE, UK

${ }^{t}$ Eurofins Villapharma Research, S.L., Avda. Isaac Peral, Parque Tecnológico de Fuente Álamo, Ctra. El Estrecho-Lobosillo, 30320 Murcia, Spain

${ }^{\circ}$ Charles River Labs Beerse, Turnhoutseweg 30, 2340 Beerse, Belgium

KEYWORDS. Influenza, indole, bioisostere

\begin{abstract}
In the search for novel influenza inhibitors we evaluated 7-fluoro-substituted indoles as bioisosteric replacements for the 7-azaindole scaffold of Pimodivir, a PB2 (polymerase basic protein 2) inhibitor currently in clinical development. Specifically, a 5,7-difluoroindole derivative 11a was identified as a potent and metabolically stable influenza inhibitor. 11a demonstrated a favorable oral pharmacokinetic profile and in vivo efficacy in mice. In addition, it was found that
\end{abstract}


11a was not at risk of metabolism via aldehyde oxidase, an advantage over previously described inhibitors of this class. The crystal structure of 11a bound to influenza A PB2 cap region is disclosed here and deposited to the PDB.

\section{INTRODUCTION}

Influenza is an infectious disease affecting the upper respiratory tract and often the lungs and is caused by the influenza virus. Recent data show that every year, 3 to $11 \%$ of the US population become infected with influenza virus and some require hospitalization. ${ }^{1}$ The ability of influenza to be transmitted from animals to human makes it particularly dangerous and has led to global pandemics. ${ }^{2}$ While vaccination is recommended to reduce infection rates and decrease the likelihood of an epidemic, it is not efficacious for everyone, with $50-60 \%$ effectiveness at reducing the infection risk in the global population, and nearly $60 \%$ effective at reducing morbidity in the elderly. This may be due to the way the vaccine is designed (i.e. live attenuated vs. inactivated influenza vaccines), the relatively low vaccination rates in some countries, or that the predominant seasonal viral strain has evaded the host immune system due to antigenetic drift. ${ }^{1,3}$

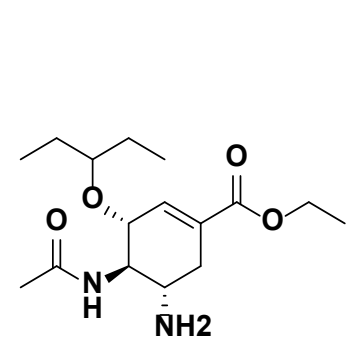

Oseltamivir (1)

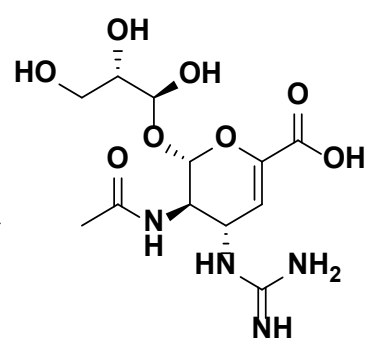

Zanamivir (2)

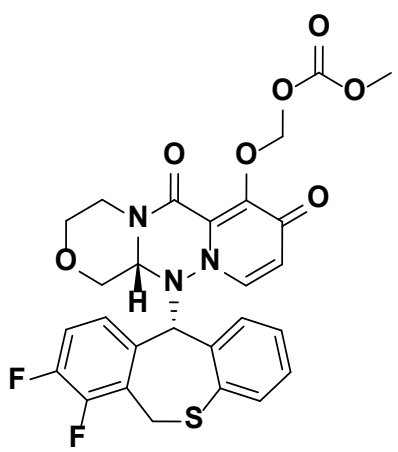

Xofluza (3)

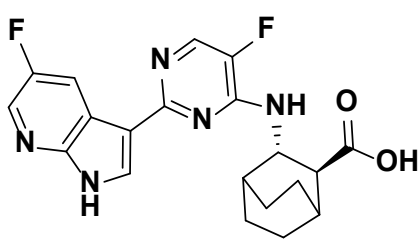

Pimodivir (4)

Figure 1. Selected anti-influenza agents. 
Among the classes of approved influenza inhibitors are the neuraminidase inhibitors, that are the current standard of care. Oseltamivir (1) is given orally, and Zanamivir (2) is marketed for inhalation. Recently, Xofluza (3) was approved as a first-in-class drug with a novel mechanism of action targeting the viral cap-dependent endonuclease. It is reported to be effective against Oseltamivir-resistant strains. ${ }^{4}$ These agents are highly effective against influenza types A and B but share a common drawback, as they must be administered within the first few days of infection, and preferentially before the onset of symptoms to make meaningful therapeutic impact. ${ }^{5}$ Furthermore, resistance has been shown to occur for neuraminidase ${ }^{6}$ and endonuclease inhibitors. ${ }^{7}$ Thus, there is an immediate medical need for new drugs to cover novel mechanisms of action that could be used seasonally or to help prevent a future pandemic. ${ }^{8}$ Pimodivir (4) is described as a PB2 cap binder, ${ }^{9}$ and is currently in clinical development for the treatment of severe influenza infection in high risk and hospitalized patients. ${ }^{10} \mathrm{~PB} 2$, a subunit of the influenza virus RNA polymerase complex, plays an essential role in transcription initiation and the cap-stealing mechanism, and acts as a virulence determinant. ${ }^{11}$

\section{MEDICINAL CHEMISTRY STRATEGY}

The recent publication of the crystal structure of $\mathbf{4}$ bound to the cap region has led research groups to pursue new influenza inhibitors. One strategy of exploring new inhibitors is to systematically explore each ring system of $\mathbf{4}$ and replace selected groups by moieties having similar biological properties, termed bioisosteres, ${ }^{12}$ that could modify the activity or reduce offtarget activity. The design of bioisosteric replacements is a valuable strategy to develop alternative drug candidates in a scaffold-hopping exercise to potentially address aspects of lead candidates. ${ }^{13}$ We envisioned that the fluoroindole could be an effective bioisostere of the 7azaindole ring system with differentiated properties (e.g. polar surface area and calculated $\log \mathrm{P}$ ) 
and would have the potential to find application in other targets (e.g. nucleoside bases). Indeed, bioisosteres of 4 have been described wherein the acid motif was replaced by a heterocycle, ${ }^{14}$ also the central pyrimidine ring of $\mathbf{4}$ was bioisosterically exchanged for pyrimidine-fused heterocycles. ${ }^{15}$ This work covers the first described bioisostere of 7 -azaindole, resulting in an influenza inhibitor that is effective in vivo and has reduced off-target activity.

Examining the structure of $\mathbf{4}$, we reasoned that a carbon-fluorine bond could act as hydrogen bond acceptor. ${ }^{16}$ Evidence of a similar scaffold-hopping exercise was described in the literature where 7-fluoro-7-deazaadenosine-nucleotide was incorporated as efficiently as adenosine into T7 RNA polymerase, despite lacking the nitrogen and possessing a different $\mathrm{pKa}$ value. ${ }^{17}$ This intriguing fact provides rationale for new possibilities in medicinal chemistry scaffold design, in that the small fluorine group can have minimal structural influence, yet imitate an aromatic nitrogen atom, allowing the molecule to adopt a similar binding mode.

\section{CHEMISTRY}

The first Pimodivir analog of interest was the 5,7-difluoroindole bioisostere. In addition, other substituents in the indole-5-position that were of similar size or electronic character were selected for comparison (e.g. 5- $\mathrm{CH}_{3}$, vide infra).

The synthesis towards the first example, 5,7-difluoroindole analogue 11a, began with commercially available 5,7-difluoroindole (5a) as shown in Scheme 1. The indole nitrogen was tosyl protected in phase transfer catalyst conditions, resulting in 6a in high yield, which facilitated subsequent bromination with NBS in dichloromethane (7a). The aryl bromide was then reacted with bis(pinacolato)diboron under standard conditions to afford boronic ester $\mathbf{8 a}$ in modest yield (52\%). The pyrimidine bicyclo[2.2.2]octane aminoester (9) was prepared 
according to literature, ${ }^{10}$ and coupled with $\mathbf{8 a}$ under standard Suzuki-Miyaura reaction conditions. Hydrolysis of the ester using lithium hydroxide in a dioxane and water mixture afforded 11a, the first example bioisostere of 4 . The corresponding 5-chloro-7-azaindole analogue was described as potent and cell penetrant, ${ }^{10}$ and was thus also prepared. In addition, compounds $\mathbf{5 c}$ and $\mathbf{5 d}$ were prepared as the methyl group shares the same relative size as the chlorine, and a nitrile would have electron withdrawing properties like that of fluorine. ${ }^{18}$

The synthesis varied slightly for each of the remaining targeted indole influenza inhibitors. For example, in the tosyl protection step to form $\mathbf{6 c}, \mathrm{NaH}$ in DMF was used in the absence of a phase transfer catalyst in high yield (92\%). Another variation was in the bromination step to form 3bromo-5-cyano-7-fluoro-1-tosyl-1H-indole (7d) where molecular bromine was employed in dichloromethane. Trivial disparities in the Miyaura borylation and subsequent Suzuki-Miyaura reactions are detailed in the experimental section. Finally, in the last step, the base catalyzed hydrolysis to form the final indole inhibitors 11a-d, had some differences in the choice of base and means of purification and resulted in a wide range of yields (7 to $79 \%$ ).

Scheme 1. General synthetic route toward $(2 S, 3 S)-3-((2-(5-R-7-f l u o r 0-1 H$-indol-3-yl)-5fluoropyrimidin-4-yl)amino)bicyclo[2.2.2] octane-2-carboxylic acids (11a-d).

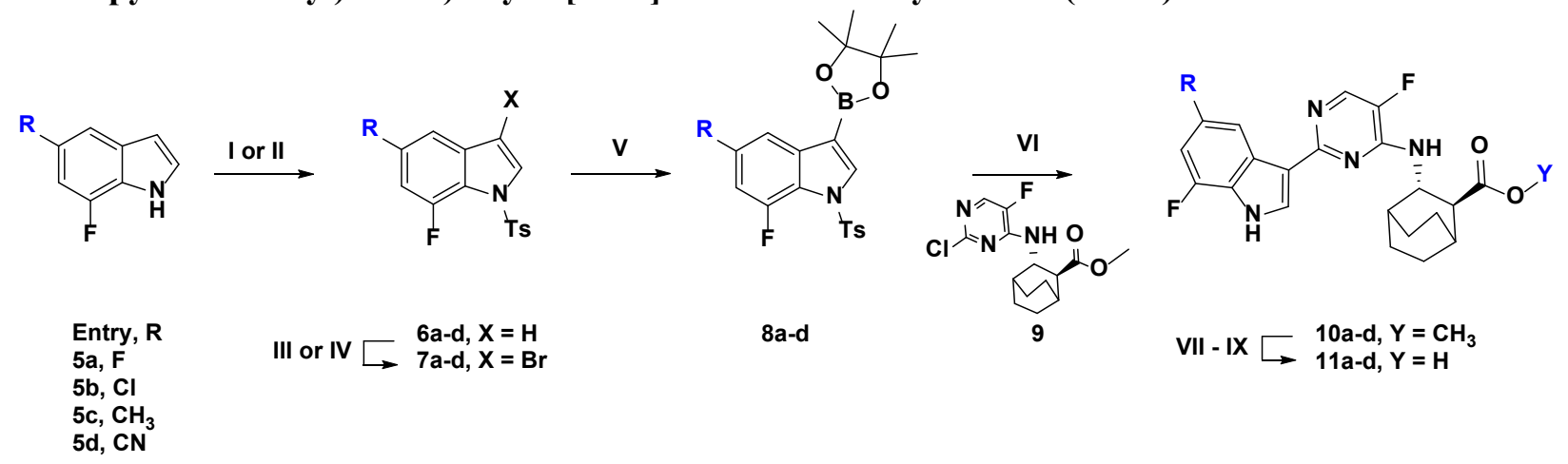

Reagents and conditions: I) TsCl, $\mathrm{NaOH} /$ toluene, TBAHS, rt, 2-3h, 63-91\% or II) $\mathrm{TsCl}, \mathrm{NaH}, \mathrm{DMF}, 0^{\circ} \mathrm{C}$ to $\mathrm{rt}, 2 \mathrm{~h}$, $92 \%$ III) NBS, $\mathrm{CH}_{2} \mathrm{Cl}_{2}$, rt, $18 \mathrm{~h}, 68-93 \%$, or IV) $\mathrm{Br}_{2}, \mathrm{CH}_{2} \mathrm{Cl}_{2}, 0^{\circ} \mathrm{C}$ to rt over $1.5 \mathrm{~h}, 76 \% \mathrm{~V}$ ) bis(pinacolato)diboron, $\mathrm{PdCl}_{2}$ (dppf), $\mathrm{KOAc}$, dioxane, $90^{\circ} \mathrm{C}$ for $\left.18 \mathrm{~h}, 45-96 \% \mathrm{VI}\right) \mathrm{PdCl}_{2}(\mathrm{dppf}), \mathrm{K}_{3} \mathrm{PO}_{4}$, dioxane, water, microwave $100^{\circ} \mathrm{C}, 32-$ 68\% VII) For 11a,b; LiOH, dioxane, water, rt, 18h, 71- 79\% VIII) For 11c; KOH, EtOH, $80^{\circ} \mathrm{C}, 40$ min, $7 \%$ IX) For 11d; $\mathrm{NaOCH}_{3}, \mathrm{CH}_{3} \mathrm{OH}$, rt for $18 \mathrm{~h}, 64 \%$. 


\section{RESULTS AND DISCUSSION}

The cellular antiviral activity of 11a-d were tested against three influenza A strains, two H1N1 strains and one H3N2 strain, and cytotoxicity was measured in MDCK and A549 cells (Table 1). All tested analogues had a cellular potency in the low nM range (Oseltamivir and Favipiravir were used as reference molecules). Higher selectivity indices $\left(\mathrm{CC}_{50} / \mathrm{IC}_{50}\right)$ were observed in the A549 cell line (derived from human alveolar epithelium) compared to MDCK cells (derived from madin-darby canine kidney), but comparable for the four analogues within each cell line.

Table 1. Antiviral activity of indole variations against three influenza A virus strains and cytotoxicity in MDCK and A549 cells.<smiles>[R]c1cc(F)c2[nH]cc(-c3ncc(F)c(N[C@H]4C5CCC(C5)[C@H]4C(=O)O)n3)c2c1</smiles>

\begin{tabular}{|c|c|c|c|c|c|c|c|}
\hline \multirow{2}{*}{ Compound } & \multirow{2}{*}{$\mathrm{R}$} & \multicolumn{2}{|c|}{ A/Taiwan/1/86 a,c } & \multicolumn{2}{|c|}{ A/Virginia/3/1975 a,c } & \multicolumn{2}{|c|}{ A/Puerto Rico/8/34 ${ }^{\mathrm{a}, \mathrm{d}}$} \\
\hline & & $\mathrm{IC}_{50} \mathrm{~b}, \mathrm{nM}$ & $\mathrm{SI}^{\mathrm{e}}$ & $\mathrm{IC}_{50}^{\mathrm{b}}, \mathrm{nM}$ & $\mathrm{SI}^{\mathrm{e}}$ & $\mathrm{IC}_{50}^{\mathrm{b}}, \mathrm{nM}$ & $\mathrm{SI}^{\mathrm{e}}$ \\
\hline $11 \mathrm{a}$ & $\mathrm{F}$ & 11 & 145 & 14 & 114 & 22 & $>1142$ \\
\hline 11b & $\mathrm{Cl}$ & 21 & 83 & 47 & 28 & 53 & $>485$ \\
\hline $11 \mathrm{c}$ & $\mathrm{CH}_{3}$ & 4 & 75 & 11 & 25 & 22 & 1491 \\
\hline 11d & $\mathrm{CN}$ & 11 & 97 & 19 & 59 & 43 & $>612$ \\
\hline Reference $^{f}$ & & 16,800 & $>6$ & 35,700 & $>3$ & 31 & $>4132$ \\
\hline
\end{tabular}

${ }^{\mathrm{a}} \mathrm{A} /$ Taiwan/1/86 and A/Puerto Rico/8/34 are H1N1 strains, A/Virginia/3/1975 is a H3N2 strain.

${ }^{\mathrm{b}} \mathrm{IC}_{50}$ is the $50 \%$ inhibiting concentration, i.e. the concentration causing $50 \%$ decrease of viral replication.

${ }^{\mathrm{c}}$ MDCK cells.

d A549 cells.

${ }^{\text {e }} \mathrm{SI}$ selectivity index, $\mathrm{CC}_{50} / \mathrm{IC}_{50}$.

${ }^{\mathrm{f}}$ Reference molecules used: Favipiravir in MDCK cells, and Oseltamivir in A549 cells.

The biochemical binding affinity of the analogues to the PB2 cap binding domain of influenza A and $\mathrm{B}$ was assessed in a Lance Ultra ${ }^{\circledR}$ competitive binding assay (Table 2). In this assay, influenza A affinities were comparable for the tested analogues, and a trend was observed towards influenza B affinity, albeit in $\mu \mathrm{M}$ range, for 11c and 11d. 
Table 2. Inhibition of CAP-Binding ( $\gamma$-[6-aminohexyl]-GTP-biotin ligand) to A/Victoria/3/1975 and B/Brisbane/60/2008 PB2CAP-binding domains. ${ }^{a}$

\begin{tabular}{ccc}
\hline Compound $^{\mathrm{a}}$ & $\begin{array}{c}\mathrm{A} / \text { Victoria/3/1975 } \\
\mathrm{IC}_{50} \mathrm{~b}, \mu \mathrm{M}\end{array}$ & $\begin{array}{c}\mathrm{B} / \text { Brisbane }^{\mathrm{b}} / 60 / 2008 \\
\mathrm{IC}_{50} \mathrm{~b}, \mu \mathrm{M}\end{array}$ \\
\hline 11a & 0.12 & $>50$ \\
11b & 0.17 & $>50$ \\
11c & 0.12 & 26 \\
11d & 0.08 & 13 \\
\hline
\end{tabular}

${ }^{\mathrm{a}}$ All compounds have been tested in the Protein L Lance Ultra counter screen that assessed non-specific technology binders. IC 50 values of $>50 \mu \mathrm{M}$ were obtained for all compounds. A/Victoria/3/1975 is an H3N2 strain.

${ }^{\mathrm{b}} \mathrm{IC}_{50}$ is the $50 \%$ inhibiting concentration, i.e. the concentration causing $50 \%$ decrease in CAP-binding.

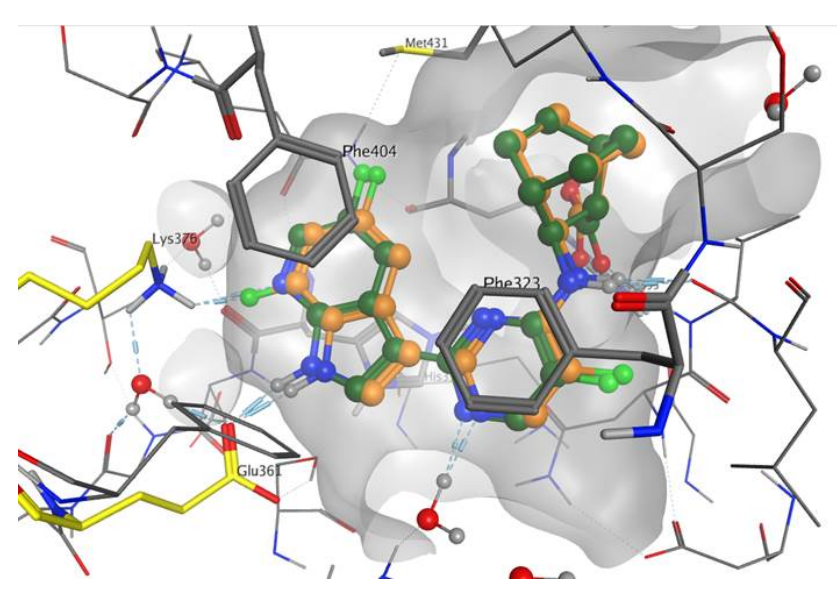

Figure 2. Superposition of 4 (dark green) and 11a (orange). The binding pocket is shown as a surface. The hydrogen bonding network formed between the protein (with Lys376 and Glu361, highlighted residues in bright yellow) and the ligands is shown as dotted lines between the ligand and the protein residues, the CF-lysine interaction of 11a is very similar to the $N$-lysine interaction of 4 .

Initially, without access to a crystal structure, a docking experiment was done, using the previously reported crystal structure (PDB ID: 5WL0), to better understand the role of the 7-fluoroindole and the influence on the binding mode (Fig. 2). The distance between the fluorine atom in the 7position of the 5,7-difluoroindole of 11a and the terminal nitrogen atom of the amino group of Lys 376 is $2.5 \AA$ with an angle of $156^{\circ}$. As a comparison, the related 7 -azaindole nitrogen of 4 and the terminal amino group of Lys376 distance is $3.4 \AA$. The fact that C-F groups can act as weak H-bond acceptors, ${ }^{16,19}$ and given the close proximity of $2.5 \AA$, it is conceivable that there is a weak hydrogen bond or dipole interaction occuring. Indeed, similar configurations in the PDB are 
observed where the fluorine on an aromatic ring is in proximity of less than $3.2 \AA$ to the terminal amino group of lysine side chain having N-F-C angles that ranged from $70^{\circ}$ to $160^{\circ}$ (Table S1). The docking and the presence of formerly crystalized ligands in a similar environment supports the rationale of the potential use of fluorine on aromatic rings as a hydrogen bond acceptor and allows us to use the model to design new compounds.

Structure analysis by X-ray diffraction was performed to obtain a more definitive assessment of the binding mode. The best crystal diffracted to a resolution of $1.35 \AA$ and was refined to $R_{\text {work }} / R_{\text {free }}$ values of $14.7 \% / 16.5 \%$. The two molecules in the asymmetric are essentially identical with an RMSD of 0.23 over all Ca-atoms. The cap-binding domain is in the "transcriptionally inactive" conformation similar to that seen for the influenza $\mathrm{C}$ polymerase heterotrimer in the absence of viral RNA and previously determined structures of the cap midlink domains with cap analogues (Fig.3A). ${ }^{20-22}$

A very clear electron density was observed for 11a and was placed unambiguously (Fig 3B). Interestingly, though unlikely to be biologically relevant, an additional molecule of 11a that mediates crystal contacts was observed. The cap-binding domain provides many of the residues that interact with compound 11a. The indole moiety of 11a forms $\pi$-stacking interactions residues Phe404 and His357, as well as ionic interactions with Glu361 and Lys376. Additional interactions with 11a from the cap-binding domain are provided by Phe323 that forms $\pi$-stacking with the pyrimidine ring, and Arg355 that forms two ionic interactions with the carboxylate of 11a. Consistent with previous observations an ionic interaction between the backbone carboxyl of Val511 from the 627-link domain with the amine at the 4-position of the pyrimidine of 11a was observed. $^{22}$ 
Comparison to the previously determined structures of $\mathbf{4}$ in complex with a similar cap-midlink construct to that used in this study (PBD ID: 6EUV) shows a globally similar structure with local points of difference (Fig. 3 C/D). At the purine end of the molecule, where the 7 -azaindole nitrogen from 4 is substituted with C-F in 11a, Lys376 that previously interacted with the nitrogen now forms an interaction with the fluorine group. The change in this interaction pushes 11a approximately $0.8 \AA$ out of the pocket. The movement out of the pocket facilitates a rotation of the carboxylate group $90^{\circ}$ such that it can now form two ionic interactions with Arg355 rather than one. The global outcome of the new binding position of 11a is that the cap binding site, created between the cap binding and mid/627-link domains is in a more open conformation, consistent with the predicted mode of binding.

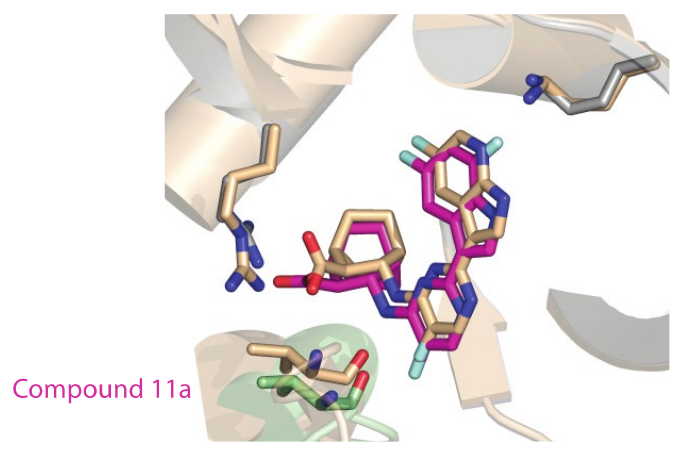

Figure 3. A) Domain arrangement of the mid (dark red), cap-binding (gold), and 627-link domains (green). B) Detail of binding of 11a with important residues and interaction distances for key residues (PDB ID: $6 \mathrm{~S} 5 \mathrm{~V}$ ). Electron density is contoured at $3 \sigma . \mathrm{C}$ ) Opening of the binding site in the presence of 4 (purple) (PDB ID: 6EUV) and 11a (colored as per panel A). D) Detailed interactions for the binding of 11a vs 4 (distances shown for 4). 
A comparison of the in vitro metabolic stability of the four inhibitors showed that the 5,7difluoroindole 11a had superior stability in human liver microsomes $\left(\mathrm{Cl}_{\text {int }}<7.7 \mu \mathrm{L} / \mathrm{min} / \mathrm{mg}\right.$ protein). In addition, 11a was found to be a crystalline solid as a free base, an advantageous property for further development. 11a was found to be inactive across a panel of 59 kinases, including GSK3$\beta$ (no inhibition at $1 \mu \mathrm{M}$ ), had no toxicity in the AMES II test, and permitted no formation of micronuclei in TK-6 cells. As an early cardiovascular safety assessment, 11a showed a lack of significant binding to sodium or potassium hERG channels $(>10 \mu \mathrm{M})$. A differentiating factor was that 11a does not show aldehyde oxidase (AO) metabolism in human liver cytosol $(1 \mathrm{~h}$, $1 \mu \mathrm{M})$, contrary to the previously reported 7 -azaindole inhibitors. ${ }^{14,23}$

The pharmacokinetic profile of 11a in mice was investigated based on the encouraging potent in vitro inhibition of influenza and confirmed target engagement in the PB2 cap binding region. The mouse plasma protein binding was high, and similar to human (99.92\%). 11a was administered orally to healthy balb/c mice at a dose of $10 \mathrm{mg} / \mathrm{kg}$. The compound was found to be rapidly absorbed with a $\mathrm{T}_{\max }$ between 0.5 and $2 \mathrm{~h}$ and demonstrated good oral bioavailability (Table 4). A satellite group $(n=3)$ was dosed p.o. to determine the lung and plasma concentrations of 11a at 7h. Mean plasma concentration was $1005 \mathrm{ng} / \mathrm{mL}$ and mean lung concentration was $491 \mathrm{ng} / \mathrm{g}$ affording a lung/plasma ratio of approximately 0.5 . Higher clearance was observed in dogs despite greater liver microsomal stability, nevertheless bioavailability remained favorable.

Table 4. Mean Pharmacokinetic parameters following single oral dose of 11a in mice and dogs."

\begin{tabular}{|l|c|c|c|c|c|c|c|}
\hline Species & Dose & PPB & $\begin{array}{c}\mathrm{Cl}_{\text {int, Microsomes }} \\
\text { in vitro } \\
(\mu \mathrm{L} / \mathrm{min} / \mathrm{mg} \text { protein })\end{array}$ & $\begin{array}{c}\mathrm{C}_{\max } \\
(\mathrm{ng} / \mathrm{mL})\end{array}$ & $\begin{array}{c}\mathrm{AUC}_{\text {last }} \\
(\mathrm{hr} \text { ng/mL })\end{array}$ & $\mathrm{T}^{1 / 2}(\mathrm{~h})$ & $\mathrm{F}(\%)$ \\
\hline Mouse & 10 & 99.90 & 15 & $3490 \pm 1200$ & $16100 \pm 2420$ & 3.6 & $95 \pm 14$ \\
\hline Dog & 2.5 & 99.94 & $<7.7$ & $1090+/-505$ & $3020+/-719$ & 5.8 & $68 \pm 11$ \\
\hline
\end{tabular}

*PEG400 was used as the vehicle. 
Compound 11a was consequently selected for evaluation in a mouse lethal infection model induced by influenza A/Puerto Rico/8/34 (H1N1) using female balb/c mice. Therapeutic efficacy, with $75 \%$ survival observed at day 21 post infection, was demonstrated when the compound was administered orally for 10 days twice daily at $30 \mathrm{mg} / \mathrm{kg}$ starting 48 hours post infection. (Fig. 4). In addition, an initial significant body weight loss was observed in this treatment setting due to the infection, however, the animals regained weight from day 11 and increased onwards (Figure S2). Tamiflu was included as a reference compound, where mice showed $38 \%$ survival at day 21 post infection in a therapeutic setting $(10 \mathrm{mg} / \mathrm{kg}$ oral b.i.d. treatment for 10 days starting 48 hours post infection) (Figure 4).

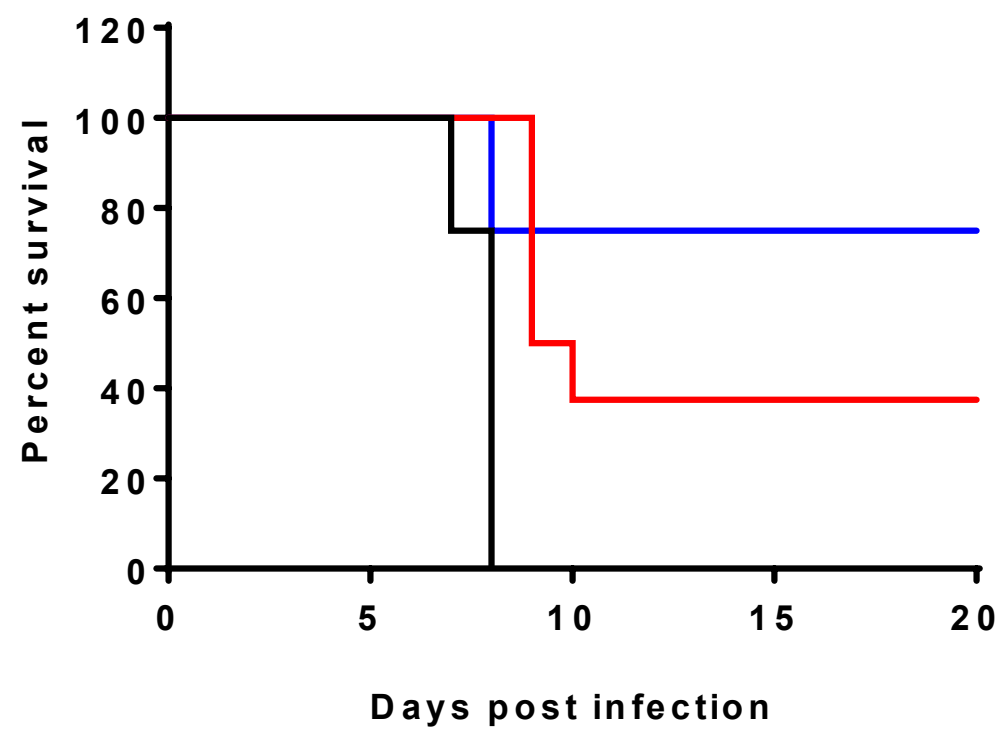

Figure 4. Mouse in vivo efficacy of 11a administered orally $(30 \mathrm{mg} / \mathrm{kg}) 48 \mathrm{~h}$ post infection for 10 days BID to female balb/c mice ( $\mathrm{n}=8 /$ group) inoculated with influenza A/Puerto Rico/8/34 (blue). Tamiflu (10 $\mathrm{mg} / \mathrm{kg}$ orally BID; treatment start 48 hours post infection and for 10 days) was included as a reference compound (red). Vehicle-treated group (PEG400) is shown in black. See figure S2, body weight as percent change from baseline, in the supporting information.

\section{CONCLUSIONS}


In conclusion, we have identified 7-fluoroindole as a bioisostere of 7-azaindole. This novel class of indole-based influenza inhibitors demonstrated target engagement by binding to influenza PB2 in the binding assay as well as potent inhibition of virally infected cells. In particular, the more metabolically stable 5,7-difluoroindole analog 11a demonstrated value as a bioisostere for the 7azaindole in 4 and was effective as an influenza PB2 inhibitor. Oral administration of 11a demonstrated high exposure in mice and dogs, distribution to target tissue, and in vivo efficacy was shown in a mouse lethal infection model. The benefit of the 7-fluoroindole also likely led to the reduced kinase activity and the dearth of aldehyde oxidase metabolism.

\section{EXPERIMENTAL SECTION}

Chemistry. Reagents and solvents were purchased from commercial sources and used without further purification. NMR spectra were recorded on a Bruker 400, 500, or $600 \mathrm{MHz}$ spectrometer. Chemical shifts and multiplicity data are given according to the ACS NMR guidelines. High resolution mass spectrometry was performed on a Waters Acquity ${ }^{\circledR}$ IClass UPLC $^{\circledR}$-DAD and Xevo G2-S QTOF. The samples were run on a Waters BEH C18 (1.7 $\mu \mathrm{m}, 2.1$ x $50 \mathrm{~mm}$, at $50^{\circ} \mathrm{C}$ ) column using reverse phase chromatography with a gradient from $95 \% \mathrm{~A}$ to 5\% $\mathrm{A}$ in 4.6 minutes, held for 0.4 minutes (A: 95\% $6.5 \mathrm{mM} \mathrm{CH}_{3} \mathrm{COONH}_{4} / 5 \% \mathrm{CH}_{3} \mathrm{CN}$, B: $\mathrm{CH}_{3} \mathrm{CN}$ ). All compounds have purity greater than $97 \%$.

5,7-difluoro-1-tosyl-1H-indole (6a). 5,7-difluoroindole (500 mg, $3.27 \mathrm{mmol}$ ) was added to toluene $(8 \mathrm{~mL})$ while stirring under nitrogen. Tetrabutylammonium hydrogen sulfate $(83 \mathrm{mg}$, $0.25 \mathrm{mmol})$ was added followed by $\mathrm{NaOH}\left(50 \%\right.$ in $\left.\mathrm{H}_{2} \mathrm{O}, 5 \mathrm{~mL}\right)$ and the mixture was stirred vigorously. A solution of $p$-toluenesulfonyl chloride $(654 \mathrm{mg}, 3.43 \mathrm{mmol})$ in toluene $(8 \mathrm{~mL}) \mathrm{was}$ added and the mixture was stirred for $3 \mathrm{~h}$ at room temperature. The organic layer was separated 
and washed with water, dried over $\mathrm{MgSO}_{4}$, the solids were removed by filtration, and the filtrate was concentrated under reduced pressure to afford the titled compound as a white solid ( $0.9 \mathrm{~g}$, 88\%). ${ }^{1} \mathrm{H}$ NMR (400 MHz, DMSO-d6) $\delta 7.98(\mathrm{~d}, J=3.52 \mathrm{~Hz}, 1 \mathrm{H}), 7.79$ (d, J=7.70 Hz, 2H), 7.43 (d, $J=7.72 \mathrm{~Hz}, 2 \mathrm{H}), 7.33(\mathrm{dd}, J=2.31,8.47 \mathrm{~Hz}, 1 \mathrm{H}), 7.17$ (ddd, $J=2.20,9.68,12.10 \mathrm{~Hz}, 1 \mathrm{H}), 6.91$ (dd, $J=2.31,3.63 \mathrm{~Hz}, 1 \mathrm{H}), 2.35(\mathrm{~s}, 3 \mathrm{H}) . \mathrm{MS}(\mathrm{ESI}) \mathrm{m} / z: 325.1\left[\mathrm{M}+\mathrm{NH}_{4}\right]^{+}$(calcd for $^{2}$ $\left.\mathrm{C}_{15} \mathrm{H}_{15} \mathrm{~F}_{2} \mathrm{~N}_{2} \mathrm{O}_{2} \mathrm{~S}: 325.08\right)$.

5-chloro-7-fluoro-1-tosyl-1H-indole (6b). The titled compound was prepared according to the method to prepare 5,7-difluoro-1-tosyl-1H-indole, $(63 \%) .{ }^{1} \mathrm{H}$ NMR $\left(400 \mathrm{MHz}, \mathrm{CDCl}_{3}\right) \delta$ 7.76-7.82 (m, 3H), 7.24-7.31 (m, 3H), 6.95 (dd, $J=1.76,11.44 \mathrm{~Hz}, 1 \mathrm{H}), 6.60(\mathrm{dd}, J=2.20,3.74$ $\mathrm{Hz}, 1 \mathrm{H}), 2.37$ (s, 3H). MS (ESI) $m / z$ 324.2 [M+H] $]^{+}$(calcd for $\mathrm{C}_{15} \mathrm{H}_{12} \mathrm{ClFNO}_{2} \mathrm{~S}: 324.03$ ).

7-fluoro-5-methyl-1-tosyl-1H-indole (6c). $\mathrm{NaH}$ (60\% dispersion in mineral oil) (0.87 g, $21.72 \mathrm{mmol})$ was added portionwise to a solution of 7-fluoro-5-methyl- $1 H$-indole $(2.7 \mathrm{~g}, 18.1$ $\mathrm{mmol})$ in $\mathrm{DMF}(30 \mathrm{~mL})$ at $0^{\circ} \mathrm{C}$ purged with $\mathrm{N}_{2}$ flow, and then the mixture was stirred for 30 min at $0^{\circ} \mathrm{C}$. $p$-Toluenesulfonyl chloride $(3.62 \mathrm{~g}, 19.01 \mathrm{mmol})$ was added portion wise at $0^{\circ} \mathrm{C}$ then the reaction mixture was stirred for 2 hours at room temperature. The reaction mixture was poured into ice water $(90 \mathrm{~mL})$ and stirred for $10 \mathrm{~min}$. EtOAc was added and the organic layer was extracted, dried over $\mathrm{MgSO}_{4}$, the solids were removed by filtration, and the solvent of the filtrate was removed under reduced pressure to afford the titled compound (5.08 g, 92\%). ${ }^{1} \mathrm{H}$ NMR (500 MHz, DMSO- $\left.d_{6}\right) \delta$ ppm $7.84(\mathrm{~d}, J=3.8 \mathrm{~Hz}, 1 \mathrm{H}) 7.76(\mathrm{~d}, J=8.2 \mathrm{~Hz}, 2 \mathrm{H}) 7.41(\mathrm{~d}, J=8.2 \mathrm{~Hz}, 2 \mathrm{H})$ $7.22(\mathrm{~s}, 1 \mathrm{H}) 6.9(\mathrm{~d}, 1 \mathrm{H}, J=13.2 \mathrm{~Hz}) 6.82(\mathrm{dd}, J=3.6,2.4 \mathrm{~Hz}, 1 \mathrm{H}) 2.33(\mathrm{~s}, 3 \mathrm{H}) 2.31(\mathrm{~s}, 3 \mathrm{H}) . \mathrm{MS}$ (ESI) $m / z: 321.3\left[\mathrm{M}+\mathrm{NH}_{4}\right]^{+}$(calcd for $\mathrm{C}_{16} \mathrm{H}_{18} \mathrm{FN}_{2} \mathrm{O}_{2} \mathrm{~S}: 321.11$ ).

7-fluoro-1-tosyl-1H-indole-5-carbonitrile (6d). 7-fluoro-1H-indole-5-carbonitrile (1.90 $\mathrm{g}, 11.86 \mathrm{mmol})$ was added to toluene $(10 \mathrm{~mL})$ while stirring under nitrogen. Tetrabutylammonium 
hydrogen sulfate (402 mg, $1.19 \mathrm{mmol})$ was added followed by $\mathrm{NaOH}\left(50 \%\right.$ in $\left.\mathrm{H}_{2} \mathrm{O}, 10 \mathrm{~mL}\right)$ and the mixture was stirred vigorously. A solution of $p$-toluenesulfonyl chloride $(3.39 \mathrm{~g}, 17.80 \mathrm{mmol})$ in toluene $(8 \mathrm{~mL})$ was added and the mixture was stirred for $16 \mathrm{~h}$. The organic layer was separated and washed with water, dried over $\mathrm{MgSO}_{4}$, the solids were removed by filtration and the solvent of the filtrate was concentrated under reduced pressure. The crude was purified by silica column chromatography using a heptane to EtOAc gradient. The desired fractions were collected and evaporated to dryness to afford 7-fluoro-1-tosyl-1H-indole-5-carbonitrile (3.4 g, 91\%). ${ }^{1} \mathrm{H}$ NMR (400 MHz, DMSO-d $) \delta 8.12(\mathrm{~d}, J=3.74 \mathrm{~Hz}, 1 \mathrm{H}), 8.08(\mathrm{~d}, J=1.32 \mathrm{~Hz}, 1 \mathrm{H}), 7.83-7.90$ (m, 2H), 7.71 (dd, $J=1.10,12.10 \mathrm{~Hz}, 1 \mathrm{H}), 7.47$ (d, $J=8.14 \mathrm{~Hz}, 2 \mathrm{H}), 7.04$ (dd, $J=2.20,3.74 \mathrm{~Hz}, 1 \mathrm{H}), 2.37$ (s, 3H). MS (ESI) m/z: $313.2[\mathrm{M}-\mathrm{H}]^{-}$(calcd for $\mathrm{C}_{16} \mathrm{H}_{12} \mathrm{FN}_{2} \mathrm{O}_{2} \mathrm{~S}: 313.04$ )

3-bromo-5,7-difluoro-1-tosyl-1H-indole (7a). $\quad N$-bromosuccinimide $(9.64 \mathrm{~g}, 54.18$ mmol) was added portion wise to a solution of 5,7-difluoro-1-tosyl-indole (16.65 g, $54.18 \mathrm{mmol})$ in $\mathrm{CH}_{2} \mathrm{Cl}_{2}(300 \mathrm{~mL})$ at room temperature and stirred for $18 \mathrm{~h}$. The mixture was treated with a saturated aq. $\mathrm{NaHCO}_{3}$ solution and the mixture was stirred for $5 \mathrm{~min}$. The organic layer was dried $\left(\mathrm{MgSO}_{4}\right)$, the solids were removed by filtration and the solvent was removed under reduced pressure. The crude was purified by silica column chromatography using a heptane to $\mathrm{CH}_{2} \mathrm{Cl}_{2}$ gradient. The desired fractions were collected and evaporated to dryness to afford the titled compound as a tan solid (0.9 g, 79\%). ${ }^{1} \mathrm{H}$ NMR (400 MHz, DMSO- $\left.d_{6}\right) \delta 8.27(\mathrm{~s}, 1 \mathrm{H}), 7.86$ (d, $J=7.70 \mathrm{~Hz}, 2 \mathrm{H}), 7.45(\mathrm{~d}, J=7.92 \mathrm{~Hz}, 2 \mathrm{H}), 7.34(\mathrm{ddd}, J=2.31,9.63,12.05 \mathrm{~Hz}, 1 \mathrm{H}), 7.18(\mathrm{dd}, J=1.98$, $7.92 \mathrm{~Hz}, 1 \mathrm{H}), 2.36(\mathrm{~s}, 3 \mathrm{H})$. MS (ESI) $\mathrm{m} / z$ : $409.0[\mathrm{M}+\mathrm{HNa}]^{+}$(calcd for $\mathrm{C}_{15} \mathrm{H}_{11} \mathrm{BrF}_{2} \mathrm{NNaO}_{2} \mathrm{~S}$ : 408.96). 
3-bromo-5-chloro-7-fluoro-1-tosyl-1H-indole (7b). To a solution of 5-chloro-7-fluoro1-tosyl-1 $H$-indole (3.65 g, $11.27 \mathrm{mmol})$ in DMF (23 mL) was added $N$-bromosuccinimide (2.41 $\mathrm{g}, 13.53 \mathrm{mmol}$ ) at room temperature and stirred at $50^{\circ} \mathrm{C}$ for $1 \mathrm{~h}$, then at ambient temperature for 16h. The mixture was poured into ice water and stirred for $30 \mathrm{~min}$. The precipitate was isolated by filtration to afford the titled compound as a tan solid (4.20 g, 93\%). ${ }^{1} \mathrm{H}$ NMR (400 MHz, DMSO- $\left.d_{6}\right) \delta 8.28(\mathrm{~s}, 1 \mathrm{H}), 7.86(\mathrm{~d}, J=7.70 \mathrm{~Hz}, 2 \mathrm{H}), 7.41-7.50(\mathrm{~m}, 3 \mathrm{H}), 7.36(\mathrm{~d}, J=1.98 \mathrm{~Hz}, 1 \mathrm{H})$, 2.35 (s, 3H). MS (ESI) m/z: 399.9 [M-H] $]^{-}$(calcd for $\mathrm{C}_{15} \mathrm{H}_{9} \mathrm{BrClFNO}_{2} \mathrm{~S}: 399.92$ ).

3-bromo-5-methyl-7-fluoro-1-tosyl-1 H-indole (7c). $N$-Bromosuccinimide $(2.27 \mathrm{~g}, 12.75$ mmol) was added to a solution of 7-fluoro-5-methyl-1-tosyl-1 $H$-indole $(4.07 \mathrm{~g}, 12.75 \mathrm{mmol})$ in $\mathrm{CH}_{2} \mathrm{Cl}_{2}(66 \mathrm{~mL})$ at room temperature. The reaction mixture was stirred at room temperature for 18 hours. The mixture was treated with $\mathrm{NaHCO}_{3}$ (sat., aq.) and the mixture was stirred for 5 min. The organic layer separated, dried over $\mathrm{MgSO}_{4}$, the solids were removed by filtration and the solvent was evaporated to dryness. The crude was purified by silica column chromatography using a heptane to EtOAc gradient. Pure fractions were collected, and the solvent was evaporated. The residue was crystallized from EtOH, isolated by filtration, and dried under vacuum to give 3bromo-7-fluoro-5-methyl-1-tosyl-1 $H$-indole as beige powder (3.30 g, 68\%). ${ }^{1} \mathrm{H}$ NMR (400 MHz, DMSO- $\left.d_{6}\right) \delta$ ppm $8.13(\mathrm{~s}, 1 \mathrm{H}) 7.83(\mathrm{~d}, \mathrm{~J}=8.1 \mathrm{~Hz}, 2 \mathrm{H}) 7.44(\mathrm{~d}, \mathrm{~J}=8.6 \mathrm{~Hz}, 2 \mathrm{H}) 7.12(\mathrm{~s}, 1 \mathrm{H}) 7.10$ (d, J=13.6 Hz, $1 \mathrm{H}) 2.37(\mathrm{~s}, 3 \mathrm{H}) 2.35(\mathrm{~s}, 3 \mathrm{H}) . \mathrm{MS}(\mathrm{ESI}) \mathrm{m} / z: 399.3\left[\mathrm{M}+\mathrm{NH}_{4}\right]^{+}$(calcd for $\left.\mathrm{C}_{16} \mathrm{H}_{17} \mathrm{BrFN}_{2} \mathrm{O}_{2} \mathrm{~S}: 399.02\right)$.

3-bromo-7-fluoro-1-tosyl-1H-indole-5-carbonitrile (7d). To a solution of 7-fluoro-1tosyl- $1 \mathrm{H}$-indole-5-carbonitrile $(1.70 \mathrm{~g}, 5.48 \mathrm{mmol})$ in $\mathrm{CH}_{2} \mathrm{Cl}_{2}(15 \mathrm{~mL})$ was added $\mathrm{Br}_{2}(0.33 \mathrm{~mL}$, $6.50 \mathrm{mmol}$ ) at $0^{\circ} \mathrm{C}$. The mixture was stirred at $0^{\circ} \mathrm{C}$ for 30 minutes and then at room temperature for one additional hour. The reaction mixture was treated with a saturated solution of aqueous 
$\mathrm{NaHCO}_{3}$. The organic layer was separated and washed with aqueous $\mathrm{Na}_{2} \mathrm{~S}_{2} \mathrm{O}_{3}$, brine and water. The organic layer was dried over $\mathrm{MgSO}_{4}$, and concentrated. The crude was purified by silica column chromatography using a heptane to EtOAc gradient. The desired fractions were collected and evaporated to dryness to afford 3-bromo-7-fluoro-1-tosyl- $1 H$-indole-5-carbonitrile (1.6 g, 76\%). ${ }^{1} \mathrm{H}$ NMR (400 MHz, DMSO- $\left.d_{6}\right) \delta 8.43(\mathrm{~s}, 1 \mathrm{H}), 7.95(\mathrm{~d}, J=1.32 \mathrm{~Hz}, 1 \mathrm{H}), 7.92(\mathrm{~d}, J=7.70$ Hz, 2H), 7.86 (dd, $J=1.21,11.99 \mathrm{~Hz}, 1 \mathrm{H}), 7.49$ (d, $J=8.14 \mathrm{~Hz}, 2 \mathrm{H}), 2.38$ (s, 3H). MS (ESI) $m / z$ : $391.1[\mathrm{M}-\mathrm{H}]^{-}$(calcd for $\mathrm{C}_{16} \mathrm{H}_{9} \mathrm{BrFN}_{2} \mathrm{O}_{2} \mathrm{~S}: 390.96$ ).

\section{5,7-difluoro-3-(4,4,5,5-tetramethyl-1,3,2-dioxaborolan-2-yl)-1-tosyl-1 $H$-indole}

(8a). A mixture of 3-bromo-5,7-difluoro-1-tosyl-indole (2 g, $5.18 \mathrm{mmol})$, bis-pinacolatodiboron (1.45 g, $5.70 \mathrm{mmol}), \mathrm{Pd}(\mathrm{dppf}) \mathrm{Cl}_{2}$ (76 mg, $\left.0.10 \mathrm{mmol}\right), 1,1$ '-bis(diphenylphosphino)ferrocene (55 mg, $0.10 \mathrm{mmol})$ and $\mathrm{KOAc}(1.01 \mathrm{~g}, 10.36 \mathrm{mmol})$ in dioxane $(20 \mathrm{~mL})$ was heated to $90^{\circ} \mathrm{C}$ for $18 \mathrm{~h}$ under nitrogen. The reaction cooled to room temperature, the solids were removed by filtration, and the solvent of the filtrate was removed under reduced pressure. The crude was purified by silica column chromatography using a heptane to $\mathrm{CH}_{2} \mathrm{Cl}_{2}$ gradient. The desired fractions were collected and evaporated to dryness to afford the titled compound as an off-white solid $(1.99 \mathrm{~g}, 89 \%) .{ }^{1} \mathrm{H}$ NMR (400 MHz, DMSO-d6) $\delta 8.12(\mathrm{~s}, 1 \mathrm{H}), 7.89$ (d, $J=7.70 \mathrm{~Hz}, 2 \mathrm{H}), 7.44(\mathrm{~d}, J=7.92 \mathrm{~Hz}, 2 \mathrm{H}), 7.36$ (dd, $J=2.31,8.47 \mathrm{~Hz}, 1 \mathrm{H}), 7.21$ (ddd, $J=2.42,9.68,12.10 \mathrm{~Hz}, 1 \mathrm{H}), 2.36$ (s, 3H), 1.32 (s, 12H). MS (ESI) $m / z: 434.0[\mathrm{M}+\mathrm{H}]^{+}$(calcd for $\mathrm{C}_{21} \mathrm{H}_{23} \mathrm{BF}_{2} \mathrm{NO}_{2} \mathrm{~S}: 434.14$ ).

\section{5-chloro-7-fluoro-3-(4,4,5,5-tetramethyl-1,3,2-dioxaborolan-2-yl)-1-tosyl-1 $H$-indole}

(8b). The titled compound was prepared in a method analogous to that described for the 
preparation of $8 \mathrm{a}$ with the exception that the reaction was heated to $90^{\circ} \mathrm{C}$ for 16 hours $(45 \%) .{ }^{1} \mathrm{H}$ NMR (400 MHz, DMSO- $\left.d_{6}\right) \delta 8.14(\mathrm{~s}, 1 \mathrm{H}), 7.89-7.94(\mathrm{~m}, 2 \mathrm{H}), 7.64$ (d, $\left.J=1.76 \mathrm{~Hz}, 1 \mathrm{H}\right), 7.45-7.48$

(m, 2H), $7.35(\mathrm{dd}, J=1.87,11.77 \mathrm{~Hz}, 1 \mathrm{H}), 2.38(\mathrm{~s}, 3 \mathrm{H}), 1.35(\mathrm{~s}, 12 \mathrm{H})$. MS (ESI) $\mathrm{m} / z 450.0[\mathrm{M}+\mathrm{H}]^{+}$ (calcd for $\mathrm{C}_{21} \mathrm{H}_{23} \mathrm{ClFNO}_{4} \mathrm{~S}: 450.11$ ).

\section{7-fluoro-5-methyl-3-(4,4,5,5-tetramethyl-1,3,2-dioxaborolan-2-yl)-1-tosyl-1 $H$-indole}

(8c). A mixture of 3-bromo-7-fluoro-5-methyl-1-tosyl-1H-indole $(0.7 \mathrm{~g}, 1.83 \mathrm{mmol})$, bis(pinacolato)diboron $(0.7 \mathrm{~g}, 2.75 \mathrm{mmol}), \mathrm{Pd}(\mathrm{dppf}) \mathrm{Cl}_{2}(0.075 \mathrm{~g}, 0.092 \mathrm{mmol})$ and potassium acetate $(0.54 \mathrm{~g}, 5.49 \mathrm{mmol})$ in DME $(16 \mathrm{~mL})$ was purged with $\mathrm{N}_{2}$ flow for 5 min and then was stirred and heated at $100{ }^{\circ} \mathrm{C}$ for $18 \mathrm{~h}$. EtOAc $(40 \mathrm{~mL})$ was added, the reaction mixture was filtered through packed celite, the filtrate was washed with brine, dried $\left(\mathrm{MgSO}_{4}\right)$, the solids were removed by filtration, and the filtrate was evaporated to dryness. The crude was purified by silica column chromatography using a heptane to EtOAc gradient affording the titled compound (1.27 g, 96\%). ${ }^{1} \mathrm{H}$ NMR (400 MHz, DMSO- $d_{6}$ ) $\delta$ ppm 7.99 (s, $\left.1 \mathrm{H}\right) 7.85$ (d, J=8.1 Hz, 2 H) 7.37 - 7.49 (m, 3 H) $6.92-7.03(\mathrm{~m}, 1 \mathrm{H}) 2.36(\mathrm{~s}, 3 \mathrm{H}) 2.34(\mathrm{~s}, 3 \mathrm{H}) 1.33(\mathrm{~s}, 12 \mathrm{H})$. MS (ESI) $m / z: 430.3[\mathrm{M}+\mathrm{H}]^{+}$(calcd $^{2}$ for $\left.\mathrm{C}_{22} \mathrm{H}_{26} \mathrm{BFNO}_{4} \mathrm{~S}: 430.17\right)$.

\section{7-fluoro-3-(4,4,5,5-tetramethyl-1,3,2-dioxaborolan-2-yl)-1-tosyl-1 $H$-indole-5-}

carbonitrile (8d). 3-bromo-7-fluoro-1-tosyl-1 $H$-indole-5-carbonitrile (1.62 g, $4.11 \mathrm{mmol})$, bispinacolatodiboron $(3.13 \mathrm{~g}, 12.32 \mathrm{mmol}), \mathrm{Pd}(\mathrm{dppf}) \mathrm{Cl}_{2}(300 \mathrm{mg}, 0.41 \mathrm{mmol})$ and $\mathrm{KOAc}(1.81 \mathrm{~g}$, $18.48 \mathrm{mmol})$ in dioxane $(15 \mathrm{~mL})$ was heated to $80^{\circ} \mathrm{C}$ for $16 \mathrm{~h}$ under nitrogen. The reaction was cooled to room temperature, the solids removed by filtration, and the solvent of the filtrate was removed under reduced pressure. The crude was purified by silica column chromatography using a heptane to EtOAc gradient. The desired fractions were collected and evaporated to dryness to afford 7-fluoro-3-(4,4,5,5-tetramethyl-1,3,2-dioxaborolan-2-yl)-1-tosyl-1 $H$-indole-5-carbonitrile 
$(1.1 \mathrm{~g}, 60 \%) .{ }^{1} \mathrm{H}$ NMR $\left(400 \mathrm{MHz}, \mathrm{DMSO}-d_{6}\right) \delta 8.25(\mathrm{~s}, 1 \mathrm{H}), 8.02(\mathrm{~d}, J=1.32 \mathrm{~Hz}, 1 \mathrm{H}), 7.95(\mathrm{~d}$, $J=7.26 \mathrm{~Hz}, 2 \mathrm{H}), 7.76(\mathrm{dd}, J=1.21,11.99 \mathrm{~Hz}, 1 \mathrm{H}), 7.48(\mathrm{~d}, J=8.14 \mathrm{~Hz}, 2 \mathrm{H}), 2.38(\mathrm{~s}, 3 \mathrm{H}), 1.35(\mathrm{~s}$, 12H). MS (ESI) $m / z: 441.2[\mathrm{M}+\mathrm{H}]^{+}$(calcd for $\mathrm{C}_{22} \mathrm{H}_{23} \mathrm{BFN}_{2} \mathrm{O}_{4} \mathrm{~S}: 441.15$ ).

\section{Methyl $\quad(2 S, 3 S)-3-((2-(5,7-d i f l u o r o-1-t o s y l-1 H$-indol-3-yl)-5-fluoropyrimidin-4-}

yl)amino)bicyclo[2.2.2]octane-2-carboxylate (10a). A mixture of 5,7-difluoro-3-(4,4,5,5tetramethyl-1,3,2-dioxaborolan-2-yl)-1-tosyl-1H-indole (0.4 g, $0.92 \mathrm{mmol}),(2 S, 3 S)$-3-((2-chloro5-fluoropyrimidin-4-yl)amino)bicyclo[2.2.2]octane-2-carboxylate $(316 \mathrm{mg}, \quad 1 \mathrm{mmol})$ and potassium phosphate $(588 \mathrm{mg}, 2.8 \mathrm{mmol})$ was stirred in water $(1.2 \mathrm{~mL})$ and 1,4-dioxane $(6 \mathrm{~mL})$ at room temperature under nitrogen. Then $\mathrm{PdCl}_{2}(\mathrm{dtbpf})(133 \mathrm{mg}, 0.2 \mathrm{mmol})$ was added and stirred under nitrogen for 10 minutes. The vessel was closed, and the reaction was heated in the microwave for 10 minutes at $130^{\circ} \mathrm{C}$. The mixture was diluted with EtOAc and methyl-THF. Dried over $\mathrm{MgSO}_{4}$, filtered over celite and the solvent of the filtrate was removed under reduced pressure. The crude was purified by silica column chromatography using a heptane to EtOAc gradient. The corresponding fractions were evaporated and dried in vacuo to afford methyl (2S,3S)-3-((2-(5,7-difluoro-1-tosyl-1H-indol-3-yl)-5-fluoropyrimidin-4-

yl)amino)bicyclo[2.2.2] octane-2-carboxylate (0.539 g, 68\%). ${ }^{1} \mathrm{H}$ NMR (400 MHz, DMSO- $\left.d_{6}\right) \delta$ $8.53(\mathrm{~s}, 1 \mathrm{H}), 8.28(\mathrm{~d}, J=3.74 \mathrm{~Hz}, 1 \mathrm{H}), 8.23(\mathrm{dd}, J=2.42,9.02 \mathrm{~Hz}, 1 \mathrm{H}), 7.91(\mathrm{~d}, J=7.70 \mathrm{~Hz}, 2 \mathrm{H})$, 7.84 (br d, $J=6.82 \mathrm{~Hz}, 1 \mathrm{H}), 7.48$ (d, $J=8.14 \mathrm{~Hz}, 2 \mathrm{H}), 7.28$ (ddd, $J=2.31,9.41,12.05 \mathrm{~Hz}, 1 \mathrm{H}), 4.73$ (br t, $J=6.93 \mathrm{~Hz}, 1 \mathrm{H}$ ), 3.65 (s, 3H), 3.00 (br d, $J=6.82 \mathrm{~Hz}, 1 \mathrm{H}$ ), 2.38 (s, 3H), 1.98 (br d, $J=16.73$ $\mathrm{Hz}, 2 \mathrm{H}), 1.72-1.88(\mathrm{~m}, 3 \mathrm{H}), 1.36-1.68(\mathrm{~m}, 5 \mathrm{H}) . \mathrm{MS}(\mathrm{ESI}) \mathrm{m} / \mathrm{z}: 585.4[\mathrm{M}+\mathrm{H}]^{+}$(calcd for $\left.\mathrm{C}_{29} \mathrm{H}_{28} \mathrm{~F}_{3} \mathrm{~N}_{4} \mathrm{O}_{4} \mathrm{~S}: 585.18\right)$.

Methyl

(2S,3S)-3-((2-(5-chloro-7-fluoro-1 $H$-indol-3-yl)-5-fluoropyrimidin-4-

yl)amino)bicyclo-[2.2.2] octane-2-carboxylate (10b). The titled compound was prepared in a 
method analogous to that described for the preparation of 10a with the exception that in step one, the reaction was heated at $100^{\circ} \mathrm{C}$ for 15 min under microwave irradiation and 0.8 equivalent of (2S,3S)-3-((2-chloro-5-fluoropyrimidin-4-yl)amino)bicyclo[2.2.2]octane-2-carboxylate was used (39\%). ${ }^{1} \mathrm{H}$ NMR (400 MHz, DMSO- $\left.d_{6}\right) \delta 8.50(\mathrm{~d}, J=1.76 \mathrm{~Hz}, 1 \mathrm{H}), 8.48(\mathrm{~s}, 1 \mathrm{H}), 8.27-8.29(\mathrm{~m}$, 1H), $7.89(\mathrm{~d}, J=8.14 \mathrm{~Hz}, 2 \mathrm{H}), 7.84(\mathrm{br} d, J=6.60 \mathrm{~Hz}, 1 \mathrm{H}), 7.47$ (d, $J=8.14 \mathrm{~Hz}, 2 \mathrm{H}), 7.40-7.44$ (m, 1H), 4.71 (br t, $J=7.15 \mathrm{~Hz}, 1 \mathrm{H}), 3.61$ (s, 3H), 2.93-2.98 (m, 1H), 2.38 (s, 3H), 1.98 (br s, 1H), 1.87$1.93(\mathrm{~m}, 1 \mathrm{H}), 1.70-1.87(\mathrm{~m}, 3 \mathrm{H}), 1.38-1.67(\mathrm{~m}, 5 \mathrm{H}) . \mathrm{MS}(\mathrm{ESI}) \mathrm{m} / z: 601.1[\mathrm{M}+\mathrm{H}]^{+}$(calcd for $\mathrm{C}_{29} \mathrm{H}_{28} \mathrm{ClF}_{2} \mathrm{~N}_{4} \mathrm{O}_{4} \mathrm{~S}:$ 601.18).

\section{Methyl (2S,3S)-3-((5-fluoro-2-(7-fluoro-5-methyl-1H-indol-3-yl)pyrimidin-4-} yl)amino)bicyclo-[2.2.2]octane-2-carboxylate (10c). A solution of 7-fluoro-5-methyl-3(4,4,5,5-tetramethyl-1,3,2-dioxaborolan-2-yl)-1-tosyl-1 $H$-indole (1.09 g, $1.26 \mathrm{mmol})$, methyl $(2 S, 3 S)-3-((2-c h l o r o-5-f l u o r o p y r i m i d i n-4-y l) a m i n o) b i c y c l o[2.2 .2]$ octane-2-carboxylate $(0.33 \mathrm{~g}$, $1.05 \mathrm{mmol})$ and $\left[1,1^{\prime}\right.$-bis(diphenylphosphino)ferrocene]dichloropalladium(II). $\mathrm{CH}_{2} \mathrm{Cl}_{2}(0.086 \mathrm{~g}$, $0.11 \mathrm{mmol})$ in $\mathrm{K}_{2} \mathrm{CO}_{3}(2 \mathrm{M}$, aq., $2.11 \mathrm{~mL}, 4.21 \mathrm{mmol})$ and $\mathrm{DME}(14 \mathrm{~mL})$ was purged with $\mathrm{N}_{2}$ for $5 \mathrm{~min}$ and then was heated at $100^{\circ} \mathrm{C}$ using a microwave for $30 \mathrm{~min}$. The mixture was poured into water and $\mathrm{CH}_{2} \mathrm{Cl}_{2}$, the organic layer was separated and evaporated to dryness. The crude was purified by silica column chromatography using a heptane to EtOAc gradient. Pure fractions were collected, and the solvent was evaporated to give the titled compound as a white solid $(0.27 \mathrm{~g}$, 44\%). ${ }^{1} \mathrm{H}$ NMR (400 MHz, DMSO- $\left.d_{6}\right) \delta 8.39(\mathrm{~s}, 1 \mathrm{H}), 8.26(\mathrm{~s}, 1 \mathrm{H}), 8.26(\mathrm{~d}, J=3.65 \mathrm{~Hz}, 1 \mathrm{H}), 7.85$ (d, $J=7.92 \mathrm{~Hz}, 2 \mathrm{H}), 7.79$ (br d, $J=7.26 \mathrm{~Hz}, 1 \mathrm{H}), 7.44$ (d, $J=8.14 \mathrm{~Hz}, 2 \mathrm{H}), 7.04(\mathrm{~d}, J=12.98 \mathrm{~Hz}, 1 \mathrm{H})$, 4.77 (br t, $J=6.93 \mathrm{~Hz}, 1 \mathrm{H}), 3.61$ (s, 3H), 2.95 (br d, $J=7.04 \mathrm{~Hz}, 1 \mathrm{H}), 2.40$ (s, 3H), 2.36 (s, 3H), 1.97 (br s, 1H), 1.89 (br s, 1H), 1.69-1.83 (m, 3H), 1.32-1.67 (m, 5H). MS (ESI) $m / z: 581.0$ $[\mathrm{M}+\mathrm{H}]^{+}$(calcd for $\mathrm{C}_{30} \mathrm{H}_{31} \mathrm{~F}_{2} \mathrm{~N}_{4} \mathrm{O}_{4} \mathrm{~S}: 581.20$ ). 


\section{Methyl}

(2S,3S)-3-((2-(5-cyano-7-fluoro-1H-indol-3-yl)-5-fluoropyrimidin-4yl)amino) bicyclo[2.2.2]octane-2-carboxylate (10d). A solution of 7-fluoro-5-cyano-3-(4,4,5,5tetramethyl-1,3,2-dioxaborolan-2-yl)-1-tosyl- $1 H$-indole $(0.20 \mathrm{~g}, 0.45 \mathrm{mmol})$, methyl (2S,3S)-3((2-chloro-5-fluoropyrimidin-4-yl)amino)bicyclo[2.2.2]octane-2-carboxylate $(0.14 \mathrm{~g}, 0.45 \mathrm{mmol})$ and $\mathrm{Pd}(\mathrm{dppf}) \mathrm{Cl}_{2}(0.030 \mathrm{~g}, 0.05 \mathrm{mmol})$ and $\mathrm{K}_{3} \mathrm{PO}_{4}(0.29 \mathrm{~g}, 1.36 \mathrm{mmol})$ in 1,4-dioxane $(4 \mathrm{~mL})$ and $\mathrm{H}_{2} \mathrm{O}(0.4 \mathrm{~mL})$ was purged with $\mathrm{N}_{2}$ for 5 minutes and then heated to $100^{\circ} \mathrm{C}$ in the microwave for 30 minutes. The mixture was poured into water and $\mathrm{CH}_{2} \mathrm{Cl}_{2}$, the organic layer was separated and evaporated to dryness. The crude was purified via silica gel chromatography using a heptane to EtOAc gradient. Pure fractions were collected, and the solvent was removed under reduced pressure to afford the titled compound as a white solid $(0.11 \mathrm{~g}, 41 \%) .{ }^{1} \mathrm{H}$ NMR $(400 \mathrm{MHz}$, DMSO$\left.d_{6}\right) \delta 8.87(\mathrm{~d}, J=1.54 \mathrm{~Hz}, 1 \mathrm{H}), 8.58(\mathrm{~s}, 1 \mathrm{H}), 8.30(\mathrm{~d}, J=3.96 \mathrm{~Hz}, 1 \mathrm{H}), 7.94(\mathrm{~d}, J=7.48 \mathrm{~Hz}, 2 \mathrm{H}), 7.89$ (br d, $J=7.26 \mathrm{~Hz}, 1 \mathrm{H}), 7.82$ (dd, $J=1.21,11.99 \mathrm{~Hz}, 1 \mathrm{H}), 7.48$ (d, $J=8.14 \mathrm{~Hz}, 2 \mathrm{H}), 4.74$ (br t,$J=7.48$ Hz, 1H), 3.61 (s, 3H), 2.95 (br d, $J=7.26 \mathrm{~Hz}, 1 \mathrm{H}), 2.39$ (s, 3H), 1.96-2.03 (m, 1H), 1.88-1.96 (m, 1H), 1.69-1.86 (m, 3H), 1.37-1.69 (m, 5H). MS (ESI) m/z: $592.0[\mathrm{M}+\mathrm{H}]^{+}$(calcd for $\left.\mathrm{C}_{30} \mathrm{H}_{28} \mathrm{~F}_{2} \mathrm{~N}_{5} \mathrm{O}_{4} \mathrm{~S}: 592.19\right)$. 


\section{(2S,3S)-3-((2-(5,7-difluoro-1H-indol-3-yl)-5-fluoropyrimidin-4-yl)amino)bicyclo}

[2.2.2]octane-2-carboxylic acid (11a). Methyl (2S,3S)-3-((2-(5,7-difluoro-1-tosyl-1H-indol-3yl)-5-fluoropyrimidin-4-yl)amino)bicyclo[2.2.2] stirred in 1,4-dioxane $(110 \mathrm{~mL})$ at $60^{\circ} \mathrm{C}$, while a solution of $\mathrm{LiOH}(1.64 \mathrm{~g}, 68.42 \mathrm{mmol})$ in water $(20 \mathrm{~mL})$ was added. The mixture was brought to reflux for ten minutes and stirred overnight at room temperature. The solvent was removed under reduced pressure and the crude was reconstituted in water $(150 \mathrm{~mL})$, stirred and neutralized with $\mathrm{HCl}(1 \mathrm{~N}$ aq., $70 \mathrm{~mL})$. The precipitate was isolated by filtration and a purification was performed via preparatory HPLC (Uptisphere C18 ODB $-10 \mu \mathrm{m}, 200 \mathrm{~g}, 5 \mathrm{~cm}$, mobile phase: $0.25 \% \mathrm{NH}_{4} \mathrm{HCO}_{3}$ solution in water, $\mathrm{CH}_{3} \mathrm{CN}$ ) to the afford the titled compound (2.01 g, 71\%). ${ }^{1} \mathrm{H}$ NMR (360 MHz, DMSO- $\left.d_{6}\right) \delta 12.19$ (br s, $\left.1 \mathrm{H}\right), 8.15$ (d, $J=4.02 \mathrm{~Hz}, 1 \mathrm{H}), 8.06-8.12(\mathrm{~m}, 2 \mathrm{H}), 7.56$ (br d, $J=6.59 \mathrm{~Hz}, 1 \mathrm{H}), 7.02-7.09$ (m, 1H), 4.69 (br t, $J=6.77 \mathrm{~Hz}, 1 \mathrm{H}), 2.86(\mathrm{br} \mathrm{d}, J=6.95 \mathrm{~Hz}, 1 \mathrm{H}), 1.80-2.03(\mathrm{~m}, 3 \mathrm{H}), 1.69-1.79(\mathrm{~m}, 2 \mathrm{H}), 1.30-1.68(\mathrm{~m}$, 6H). ${ }^{13} \mathrm{C}$ NMR (101 MHz, DMSO-d $) \delta 176.0,158.6,151.7,145.2,142.7,139.0,138.8,131.0$, 103.1, 102.9, 97.3, 97.0, 50.8, 48.1, 28.8, 28.8, 28.7, 25.7, 24.1, 21.6, 19.5. ESI-HRMS (TOF) $m / z$ : 417.1536 [M+H] $]^{+}$(Calcd. for $\mathrm{C}_{21} \mathrm{H}_{20} \mathrm{~F}_{3} \mathrm{~N}_{4} \mathrm{O}_{2}$ : 417.1460). $[\alpha]_{\mathrm{D}}{ }^{20}-38.5$ (c 0.8, DMF).

\section{(2S,3S)-3-((2-(5-chloro-7-fluoro-1H-indol-3-yl)-5-fluoropyrimidin-4-}

yl)amino)bicyclo-[2.2.2]octane-2-carboxylic acid (11b). The titled compound was prepared in a method analogous to that described for the preparation of 11a (79\%). ${ }^{1} \mathrm{H}$ NMR $(400 \mathrm{MHz}$, DMSO$\left.d_{6}\right) \delta 8.38(\mathrm{~d}, J=1.76 \mathrm{~Hz}, 1 \mathrm{H}), 8.11(\mathrm{~d}, J=3.96 \mathrm{~Hz}, 1 \mathrm{H}), 8.09(\mathrm{~s}, 1 \mathrm{H}), 7.39$ (br d, $\left.J=6.82 \mathrm{~Hz}, 1 \mathrm{H}\right)$, $7.14(\mathrm{dd}, J=1.76,10.78 \mathrm{~Hz}, 1 \mathrm{H}), 4.72$ (br t $, J=6.71 \mathrm{~Hz}, 1 \mathrm{H}), 2.67$ (br d, $J=6.60 \mathrm{~Hz}, 1 \mathrm{H}), 1.88-2.06$ (m, 3H), 1.28-1.78 (m, 7H). ${ }^{13} \mathrm{C}$ NMR (151 MHz, DMSO-d $) \delta$ 177.1, 158.4, 151.8, 149.1, 144.0, 138.5, 131.0, 129.8, 124.4, 123.9, 117.7, 116.4, 107.9, 51.7, 49.4, 28.9, 28.8, 26.1, 24.5, 21.9, 19.8 . ESI-HRMS (TOF) $m / z$ : $433.1245[\mathrm{M}+\mathrm{H}]^{+}\left(\right.$Calcd. for $\mathrm{C}_{21} \mathrm{H}_{19} \mathrm{ClF}_{2} \mathrm{~N}_{4} \mathrm{O}_{2}$ : 433.1165). 


\section{(2S,3S)-3-((5-fluoro-2-(7-fluoro-5-methyl-1H-indol-3-yl)pyrimidin-4-}

yl)amino)bicyclo[2.2.2]octane-2-carboxylic acid (11c). A solution of methyl (2S,3S)-3-((5fluoro-2-(7-fluoro-5-methyl-1-tosyl-1H-indol-3-yl)pyrimidin-4-yl)amino)bicyclo[2.2.2]octane-2carboxylate $(1.25 \mathrm{~g}, 2.15 \mathrm{mmol})$ and $\mathrm{KOH}$ powder $(1.21 \mathrm{~g}, 21.53 \mathrm{mmol})$ in $\mathrm{EtOH}(13 \mathrm{~mL})$ was stirred and heated at $80^{\circ} \mathrm{C}$ for $40 \mathrm{~min}$. The solution was cooled to room temperature and the solvent was evaporated. The residue was taken up in water $(40 \mathrm{~mL})$ and neutralized with $\mathrm{HCl}$ (aq., $1 \mathrm{~N}, 21$ $\mathrm{mL}$ ). The mixture was stirred for 10 minutes, and then the precipitate was isolated by filtration and dried under vacuum at $50^{\circ} \mathrm{C}$ affording a beige solid. The crude was purified by silica column chromatography using a $\mathrm{CH}_{2} \mathrm{Cl}_{2}$ to $7 \% \mathrm{CH}_{3} \mathrm{OH}$ in $\mathrm{CH}_{2} \mathrm{Cl}_{2}$ gradient. Pure fractions were collected, the solvent was removed under reduced pressure. The compound was freeze-dried with acetonitrile/water: $2 / 8$ to afford the titled compound as a white powder (62 mg, 7\%). ${ }^{1} \mathrm{H}$ NMR (400 MHz, DMSO-d6) $\delta 11.86(\mathrm{~d}, J=2.00 \mathrm{~Hz}, 1 \mathrm{H}), 8.15(\mathrm{~s}, 1 \mathrm{H}), 8.12(\mathrm{~d}, J=3.96 \mathrm{~Hz}, 1 \mathrm{H}), 7.96(\mathrm{~d}, J=2.64$ Hz, 1H), 7.47 (d, J=7.00 Hz, 1H), 6.83 (d, J=12.10 Hz, 1H), 4.77 (t, J=6.80 Hz, 1H), 2.84 (d, $J=6.80 \mathrm{~Hz}, 1 \mathrm{H}), 2.42(\mathrm{~s}, 3 \mathrm{H}), 1.88-2.04(\mathrm{~m}, 2 \mathrm{H}), 1.27-1.87(\mathrm{~m}, 8 \mathrm{H}) .{ }^{13} \mathrm{C}$ NMR $(101 \mathrm{MHz}, \mathrm{DMSO}-$ $\left.d_{6}\right) \delta 176.1,159.1,151.7,150.4,148.0,145.1,142.6,138.9,130.2,129.6,123.4,117.9,108.5$, 50.8, 49.1, 48.3, 28.8, 25.8, 24.5, 21.7, 21.6, 19.4. ESI-HRMS (TOF) $m / z: 413.1789$ [M+H] ${ }^{+}$ (Calcd. for $\mathrm{C}_{22} \mathrm{H}_{23} \mathrm{~F}_{2} \mathrm{~N}_{4} \mathrm{O}_{2}$ : 413.1711). 


\section{(2S,3S)-3-((2-(5-cyano-7-fluoro-1H-indol-3-yl)-5-fluoropyrimidin-4-yl)amino)}

bicyclo[2.2.2]octane-2-carboxylic acid (11d). A 25\% w/w $\mathrm{NaOCH}_{3}(0.97 \mathrm{~mL}, 4.23 \mathrm{mmol})$ solution was added to a suspension of methyl (2S,3S)-3-((2-(5-cyano-7-fluoro-1H-indol-3-yl)-5fluoropyrimidin-4-yl)amino)bicyclo[2.2.2] octane-2-carboxylate $(0.25 \mathrm{~g}, 0.42 \mathrm{mmol})$ in $\mathrm{CH}_{3} \mathrm{OH}(2$ $\mathrm{mL}$ ) and the mixture was stirred at ambient temperature for $18 \mathrm{~h}$. The solvent was removed under reduced pressure and the crude was purified via reverse phase HPLC (from $70 \%$ [25 mM $\left.\mathrm{NH}_{4} \mathrm{HCO}_{3}\right]-30 \%\left[\mathrm{ACN}: \mathrm{CH}_{3} \mathrm{OH}, 1: 1\right]$ to $27 \%$ [25 $\left.\mathrm{mM} \mathrm{NH}_{4} \mathrm{HCO}_{3}\right]-73 \%$ [ACN: $\left.\left.\mathrm{CH}_{3} \mathrm{OH} 1: 1\right]\right)$. Pure fractions were collected, and the solvent was removed under reduced pressure to afford the titled compound as a white solid (0.115 g, 64\%). ${ }^{1} \mathrm{H}$ NMR (400 MHz, DMSO- $\left.d_{6}\right) \delta 8.75(\mathrm{~d}, J=1.10$ $\mathrm{Hz}, 1 \mathrm{H}), 8.19(\mathrm{~s}, 1 \mathrm{H}), 8.12$ (d, $J=3.96 \mathrm{~Hz}, 1 \mathrm{H}), 7.49$ (d, $J=10.78 \mathrm{~Hz}, 1 \mathrm{H}), 7.44$ (d, J=5.90 Hz, 1H), $4.74(\mathrm{t}, J=6.60 \mathrm{~Hz}, 1 \mathrm{H}), 2.63-2.69(\mathrm{~m}, 1 \mathrm{H}), 1.93-2.03(\mathrm{~m}, 2 \mathrm{H}), 1.31-1.75(\mathrm{~m}, 8 \mathrm{H}) .{ }^{13} \mathrm{C} \mathrm{NMR}(151$ MHz, DMSO-d 6 ) $\delta 176.1,157.9,151.7,148.9,149.2,144.2,138.9,131.7,129.3,127.5,124.3$, 119.8, 117.4, 109.7, 102.8, 51.0, 48.3, 28.8, 25.8, 24.5, 21.6, 19.6; ESI-HRMS (TOF). $m / z$ : 424.1590 [M+H] $]^{+}$(Calcd. for $\mathrm{C}_{22} \mathrm{H}_{20} \mathrm{~F}_{2} \mathrm{~N}_{5} \mathrm{O}_{2}:$ 424.1507).

Protein purification and Structure Determination Methods. A construct comprising the mid, cap-binding and 627-Link domains (residues 247-536) from the PB2 subunit of the Influenza A/Duck/Fujian/01/2002 (H5N1) virus polymerase was cloned into pET 151 with a N-terminal His tag and TEV protease cleavage site between the tag and protein of interest. The plasmid was transformed into chemically competent BL21 DE3 Rosetta E. Coli. A single colony was used to inoculate $20 \mathrm{~mL} \mathrm{LB}$ overnight, with this culture then used to inoculate $1 \mathrm{~L} \mathrm{LB}$. The cells were grown to an $\mathrm{OD}_{600}$ of 0.6 at $37^{\circ} \mathrm{C}$ prior to being transferred to $18^{\circ} \mathrm{C}$ where protein expression was induced with isopropyl $\beta$-D-1-thiogalactopyranoside to a final concentration of $1 \mathrm{mM}$. The cells were harvested by centrifugation after $16 \mathrm{~h}$. The cell pellet was resuspended in $20 \mathrm{~mL}$ of Buffer A 
(20 mM HEPES, pH 7.5, $300 \mathrm{mM} \mathrm{NaCl}, 5 \% \mathrm{v} / \mathrm{v}$ glycerol, $1 \mathrm{mM}$ DTT and $10 \mathrm{mM}$ imidazole) with 1 complete Protease Inhibitor cocktail tablet (Roche), $5 \mathrm{mg}$ RNAse A, and $10 \mathrm{mg}$ lysozyme before being lysed by sonication. The cell lysate was then applied to a Ni-IMAC and washed with $20 \mathrm{CV}$ of buffer A then eluted with Buffer B (Buffer A with imidazole to $300 \mathrm{mM}$ ). Fractions containing the protein were then pooled and cleaved with TEV protease for 16 hours at $4{ }^{\circ} \mathrm{C}$. The cleaved protein was then applied to a Superdex S75 Increase 10/300 column equilibrated with $20 \mathrm{mM}$ NaHEPES, pH 7.5, $150 \mathrm{mM} \mathrm{NaCl}, 0.5 \mathrm{mM}$ DTT. The protein was concentrated to $11 \mathrm{mg} / \mathrm{mL}$ for crystallization trials. Immediately prior to crystallization, $11 \mathrm{a}$ was added to the protein solution to a final concentration of $1 \mathrm{mM}$ and 5\% DMSO. Crystallization trials were set up with $100 \mathrm{~nL}$ protein and $100 \mathrm{~nL}$ reservoir solution in sitting drop vapor diffusion experiments at $20^{\circ} \mathrm{C}$. After three days large diamond crystals had formed in a condition with a reservoir solution of $10 \%$ PEG 3000, 0.2 $\mathrm{M} \mathrm{NaCl}$, and $\mathrm{K}$-citrate, $\mathrm{pH}$ 4.2. The crystals were harvested directly from screening plates and flash frozen in $\mathrm{LN}_{2}$ after being briefly passed through a cryoprotection solution containing the reservoir solution with $20 \%$ glycerol, $1 \mathrm{mM}$ compound, and 5\% DMSO. Diffraction experiments were carried out at the Diamond synchrotron on beamline I03 and the data processed with AutoProc. ${ }^{24}$ Molecular replacement was carried out in PHASER ${ }^{25}$ using the cap midlink domain from Influenza A/Victoria/3/1975 H3N2 (PDB ID 6EUV) and two molecules were found. The model was then completed with iterative rounds of manual model improvement in $\mathrm{COOT}^{26}$ and automated refinement in PHENIX. ${ }^{27}$ Ligand restraints were generated using PRODRG. ${ }^{28}$ The final model comprised residues 252 - 532, however residues 485-490 from the 627-link domain could not be placed. The model has been deposited in the PDB with the accession code (6S5V). Data collection and refinement statistics are presented in the supporting information. 
Cellular influenza antiviral activity and cytotoxicity assays. Influenza viruses A/Taiwan/1/86 (H1N1) and A/Virginia/88 (H3N2) were a kind gift from Frederick G. Hayden (University of Virginia School of Medicine). A/Puerto Rico/8/34 (H1N1) is obtained from ATCC (VR-1469 ${ }^{\mathrm{TM}}$ ). These strains were used in the cellular antiviral assays. Madin-Darby Canine Kidney MDCK cells were cultivated in Ultra-MDCK serum-free medium (BioWhittaker) with $0.4 \%$ (0.02 $\mathrm{mg} / \mathrm{ml}$ ) gentamycin (Lonza). Infections were performed in Ultra-MDCK serum-free medium supplemented with $0.02 \mathrm{mg} / \mathrm{ml}$ gentamycin and $0.0002 \%$ trypsin (Thermo Fisher Scientific) (final concentrations). Human alveolar epithelial A549 cells were cultivated in Ham's F12 medium (Thermo Fisher Scientific) supplemented with 10\% fetal bovine serum (FBS; GE Healthcare), 1\% Hepes and $0.04 \%$ gentamycin. Infections were performed in Ham’s F12 medium containing $1 \%$ Hepes, $0.04 \%$ gentamycin and 1\% FBS (final concentrations). Influenza antiviral activity in MDCK cells was determined using a cytopathic inhibition assay based on luminescence readout. MDCK cells (6,000 cells/well), Influenza A virus (multiplicity of infection or MOI 0.01) and compound (0.5\% DSMO final concentration) were incubated for 3 days $\left(37^{\circ} \mathrm{C}, 5 \% \mathrm{CO}_{2}\right)$ in 384 well plates. Each compound was tested in eleven four-fold dilution steps, starting at $25 \mu \mathrm{M}$. The cytopathic effect (CPE) was assessed by measurement of ATP levels (ATPLite ${ }^{\mathrm{TM}}$ One Step, Perkin Elmer) using a Viewlux plate reader instrument (Perkin Elmer). Influenza-induced CPE was measured by monitoring cellular ATP levels, which positively correlate with cellular viability. The antiviral activity of a compound, expressed as the $\mathrm{IC}_{50}$ value, is defined as the concentration that produced a 50\% increase in ATP levels compared to virus and no-virus controls. Influenza antiviral activity in A549 cells was determined using a neuraminidase (NA) inhibition assay, based on the NA enzyme cleaving the 2'-(4-Methylumbelliferyl)-a-D- $N$-acetylneuraminic acid (4-MUNANA; Sigma Aldrich substrate to release the fluorescent product 4-methylumbelliferone (4-MU). At day 
0, A549 cells (6,000 cells/well) were seeded in black 384-well plates containing compounds and incubated at $37^{\circ} \mathrm{C}, 5 \% \mathrm{CO}_{2}$ for 24 hours. Seeding was performed in Ham's F-12 medium supplemented with $2 \%$ FBS, $1 \%$ Hepes, and $0.04 \%$ gentamycin. Each compound was tested in nine four-fold dilution steps. The cells were subsequently infected with A/Puerto Rico/8/34 (PR8) at MOI of 1 , and plates were incubated at $37^{\circ} \mathrm{C}$ and $5 \% \mathrm{CO}_{2}$ for an additional 24 hours. Supernatant was removed and pre-heated (4-MUNANA) at $25 \mu \mathrm{M}$ in $33 \mathrm{mM}$ MES (Fisher Scientific) was added and incubated for 45 minutes at $37^{\circ} \mathrm{C}$ and $5 \% \mathrm{CO}_{2}$. Stop solution (100 mM glycine, $25 \%$ ethanol, $\mathrm{pH}$ 10.5) was added and fluorescence is measured using an Infinite M1000 instrument (Tecan) using excitation and emission filters of respectively $355 \mathrm{~nm}$ and $460 \mathrm{~nm}$. Dose-response curves were fitted and $\mathrm{IC}_{50}$ calculated. The inhibitory effect was determined based on the compound concentration that is required to reduce $50 \%$ of the NA activity, given as an $\mathrm{IC}_{50}$ value. In vitro cytotoxicity was studied in MDCK and A549 cells, with each compound tested at respectively eleven and nine four-fold dilution steps, starting at 5-100 $\mu \mathrm{M}$. Media used in the toxicity studies are Ultra-MDCK serum free medium containing $0.04 \%$ gentamycin for MDCK cells, and HAM's F12 medium containing 2\% FBS, 1\% Hepes and 0.04\% gentamycin for A549 cells. Briefly, MDCK or A549 cells (6,000 cells/well) were seeded in 384-well white plates spotted with compound. Plates were incubated for 3 days and 2 days for respectively for the MDCK or A549 assay at $37{ }^{\circ} \mathrm{C}$ at $5 \% \mathrm{CO}_{2}$ in humified incubator. The cytotoxicity was then assessed by measurement of ATP levels (ATPLite ${ }^{\mathrm{TM}}$ One Step, Perkin Elmer). The in vitro cytoxicity is expressed as $50 \%$ cytotoxic concentration $\left(\mathrm{CC}_{50}\right)$.

\section{Competitive binding studies using Lance Ultra ${ }^{\circledR}$ competitive binding assay.}

Recombinant proteins used were $N$-terminal 6xHis tagged PB2CAP domain of influenza A/Victoria/3/1975 (H3N2) covering amino acid region 320-484 (Genbank ID AFM71977; 22 
$\mathrm{kDa}$ ), C-terminal 6xHis tagged PB2CAP domain of influenza B/Brisbane/60/2008 covering amino acid region 320-484 (Genbank ID AFH57919; $20.5 \mathrm{kDa}$ ), and biotinylated Protein L carrying Nterminal 6x His tag (Arco Biosystems; RPL-P814R, $1 \mathrm{mg} / \mathrm{ml}$, 42-47 kDa). All proteins were expressed from E. coli cells. Compounds were evaluated for influenza PB2CAP binding using the Lance ${ }^{\circledR}$ Ultra technology. This is a competitive binding assay to evaluate the potency to reduce interaction between $\gamma$-[6-aminohexyl]-GTP-biotin ligand and recombinant influenza A or B PB2CAP protein. A control assay with Protein L was used to filter out nonspecific binders (e.g. biotin-like compounds). All experiments were performed in white 384-well ProxiPlates (PerkinElmer, Boston, MA) using $25 \mathrm{mM}$ HEPES pH 6.8, $50 \mathrm{mM} \mathrm{NaCl}, 1 \mathrm{mM}$ DTT and 0.005\% Tween as buffer. Compounds were tested at eleven three-fold dilution steps starting from 5 to 100 $\mu \mathrm{M}$ as the highest concentration. Ligand $\gamma$-[6-aminohexyl]-GTP-biotin ligand was obtained from Jena Bioscience (NU-834-BIO). For Influenza PB2CAP Lance ${ }^{\circledR}$ Ultra setup, ligand (resp. 6 and $1.5 \mathrm{nM}$ for Influenza A and B assay) and test compounds were added to 6xHis-tagged influenza PB2CAP (resp. 5 and $3 \mathrm{nM}$ for influenza A and B). For Protein L Lance ${ }^{\circledR}$ Ultra setup, test compounds were added to 6xHis-tagged Protein L ( $3 \mathrm{nM}$ ). For detection, Anti-His-Europium (Life technologies; PV5597; $2 \mathrm{nM}$ ) and Streptavidin-d2 (Cisbio; 610SADLB; resp. 1.5 and $0.8 \mathrm{nM}$ for Inluenza A and B assay; $2 \mathrm{nM}$ for Protein L assay) were added to the reaction mixture. After a 1hour incubation period at room temperature, time-resolved fluorescence resonance transfer (TRFRET) was measured with an EnVision plate reader instrument (Perkin Elmer). $\mathrm{EC}_{50}$ is defined at the concentration of compound with $50 \%$ displacement.

In vivo therapeutic efficacy in a mouse lethal influenza infection model. The mouse studies used pathogen-free, female 20-24g Balb/c mice (Janvier Labs; France) and were conducted at Janssen Pharmaceutica N.V (Belgium). Mice were housed under controlled conditions (specific 
pathogen free, $23^{\circ} \mathrm{C}, 60 \%$ humidity, normal light-dark cycle) and had access to food and water $a d$ libitum. Eight mice were enrolled per study group. Mice were anesthetized with 5\% isoflurane (inhalation), and influenza A/Puerto Rico/8/34 virus was introduced intranasally at $50 \mu 1 /$ nostril for a final challenge dose of $1.5 \times 10^{3} \mathrm{TCID}_{50} /$ mouse. Compound and vehicle treatment were started 48 hours post infection and administered orally twice daily for 10 days. Mice were weighed and observed for signs of morbidity daily for 21 days post infection. Any mouse that scored positive for four of the following observations $(>30 \%$ body weight loss, ruffled fur, hunched posture, respiratory distress, reduced mobility, or hypothermia) was deemed moribund, euthanized, and scored as a death in accordance with guidelines established with the Janssen Pharmaceutica N.V. Institutional Animal Care and Use Committee. The local Johnson \& Johnson Ethical Committee approved all experimental protocols, and the actual experiments were carried out strictly following the procedure described by the guidelines of the European Community Council directive of November 24, 1986 (Declaration of Helsinki 86/609/EEC). These standards meet the criteria of the ACS ethical guidelines for the publication of research. All efforts were made to minimize animal discomfort and limit the number of animals used.

Statistical analysis of biological data. In the cellular antiviral and cytotoxicity assays, for each concentration all data points were used to generate the $\mathrm{IC}_{50}$ and $\mathrm{CC}_{50}$ values through linear interpolation in the logarithmic domain. Selectivity index (SI) for each compound was calculated as the ratio of $\mathrm{CC}_{50}$ over $\mathrm{EC}_{50}$. For the competitive binding assays, curves fitting was calculated using Genedata Screener software where a standard smart fitting model is applied. $\mathrm{IC}_{50}$ values are generated based on the following equation: $\mathrm{Y}=\mathrm{S}_{\text {inf }}+\left(\mathrm{S}_{\mathrm{o}}-\mathrm{S}_{\mathrm{inf}}\right) /\left(1+10^{\wedge}\left(\left(\log \mathrm{IC}_{50}-\mathrm{X}\right) \mathrm{x}\right.\right.$ HillSlope $\left.)\right)$, with Y defined as the assay signal in the presence of compound, $\mathrm{X}$ the compound concentration, $\mathrm{S}_{\mathrm{o}}$ as positive control (high signal), $\mathrm{S}_{\mathrm{inf}}$ as negative control (low signal) and Hillslope as Hill 
coefficient. Each assay was performed in at least 3 independent runs, and the averages and standard deviations were calculated. Statistical analyses and graphical presentation for the mouse infection experiments were performed using GraphPad Prism software. Survival data were analyzed using the Kaplan Meier method, and pairwise log-rank statistics was applied for comparing pairs of survival curves. An area under the curve transformation model was used for a pairwise comparison of changes in body weight. Differences between groups were considered significant when $p<0.05$.

Evaluation of Aldehyde Oxidase (AO) Metabolism. Compound 11a was incubated in human liver cytosol $\left(1 \mu \mathrm{M}, 1 \mathrm{mg} / \mathrm{mL}\right.$ protein concentration, $\left.37^{\circ} \mathrm{C}\right)$ in the presence or absence of Raloxifene (an AO inhibitor). Serial samples were removed to 60 minutes and the percentage remaining relative to $\mathrm{t}=0$ was measured by LC-MS. No significant metabolism was observed in the presence or absence of Raloxifene suggesting that 11a is not a substrate for AO under these experimental conditions. The positive control (phthalazine) was included in this study and demonstrated AO metabolism in the normal range.

Plasma Protein Binding. Plasma protein binding. Solutions of test compound ( $1 \mu \mathrm{M}$ test compound concentration; $0.5 \%$ final DMSO concentration) are prepared in species specific plasma diluted to $25 \%$ plasma with buffer. The experiment is performed using equilibrium dialysis with the two compartments separated by a semi permeable membrane. $500 \mu \mathrm{L}$ of buffer $(\mathrm{pH} 7.4)$ is added to one side of the membrane and $300 \mu \mathrm{L}$ of the plasma solution containing the test compound is added to the other side. After equilibration for 6 hours at $37^{\circ} \mathrm{C}$ in an incubator with $5 \% \mathrm{CO}_{2}$ and agitation at $250 \mathrm{rpm}$ on an orbital shaker, samples are taken from both sides of the membrane. Following incubation, samples were removed from both the plasma (donor) and buffer (receiver) compartments and analyzed for compound content using LC-MS/MS. The fraction of 
unbound drug $\left(f_{u}\right)$ in plasma was then calculated as well as the recovery in the experiment using appropriate formulas. Two control compounds are included in each experiment.

hERG inhibition in vitro. This assay is a competitive radioligand binding assay. It measures the binding of a radiolabeled ligand to its receptor. After receptor occupation, the receptor-bound radioligand is separated from the free radioligand by filtration. In a 96-well format, radioligand and compound 11a were added to a HEK-293 membrane preparation transfected with the human Ether-à-go-go-related gene. After incubation, the unbound radioligand was removed by filtration over GF/B filters with a Filtermate 96. After overnight drying of the filter plate, microscint was added and the radioactivity bound to the receptor is measured by liquid scintillation counting in a TopCount (Packard). The results are expressed as a percent inhibition of the specific control radioligand.

\section{ASSOCIATED CONTENT}

The Supporting Information is available free of charge on the ACS Publications website at DOI: Molecular modeling details, figure S2, NMR spectra of compound 11a (PDF). Molecular formula strings and selected data (CSV).

\section{AUTHOR INFORMATION}

\section{Corresponding author}

*E-mail: dcmcgowan@yahoo.com

\section{ORCID}

David McGowan: 0000-0002-3759-6771

Werner Embrechts: 0000-0003-2880-2534

Ervin Fodor: 0000-0003-3249-196X

Jonathan Grimes: 0000-0001-9698-0389 
Jeremy Keown: 0000-0003-0159-9257

\section{Notes}

The authors declare no competing financial interest.

\section{Current address}

Pierre Raboisson, Aligos Belgium, Gaston Geenslaan 1, Heverlee, 3001 Belgium.

\section{ACKNOWLEDGEMENTS}

The authors would like to thank Lieve Bunkens and Géry Dams (Charles River) for careful review of biological methods and results, Roel Straetemans (Janssen Pharmaceutica N.V.) for biostatistical support in calculations and analysis of biological data, and Alberto Fontana for HRMS data. The authors would like to thank the I03 beamline at Diamond Light source (proposal MX14744). This work was supported by a Medical Research Council program grant MR/R009945/1 (E.F.) and a Wellcome Investigator Award 200835/Z/16/Z (J.M.G.).

\section{REFERENCES}

1) The Center for Disease Control. https://www.cdc.gov/flu/keyfacts.htm (accessed May 19, 2019). NIH RePORT, https://report.nih.gov/NIHfactsheets/ViewFactSheet.aspx?csid=133 (accessed May 19, 2019). OECD website (accessed June 11, 2019), https://data.oecd.org/healthcare/influenza-vaccination-rates.htm

2) Paules, C.; Subbarao, K. Influenza Lancet 2017, 390, 697-708. DOI: 10.1016/S01406736(17)30129-0. (b) Gao, R. ; Cao, B. ; Hu, Y. ; Feng, Z. ; Wang, D. ; Hu, W. ; Chen, J. ; Jie, Z. ; Qiu, H. ; Xu, X. ; Lu, H. ; Zhu, W. ; Gao, Z. ; Xiang, N. ;Shen, Y. ; He, Z. ;Gu, Y. ; Zhang, Z. ; Yang, Y. ;Zhao, X. ; Zhou, L. ; Li, X. ; Zou, S. ; Zhang, Y. ; Li, X. ; Yang, L. ; Guo, J. ; Dong, J. ; Li, Q. ; Dong, L. ; Zhu, Y. ; Bai, T. ; Wang, S. ; Hao, P. ; Yang, W. ; Zhang, Y. ; Han, J. ; Yu, H. ; Li, D. ; Gao. G. ; Wu, G. ; Wang, Y. ; Yuan, Z. ; Shu, Y. Human infection with a novel avian-origin influenza A (H7N9) virus. N. Engl. J. Med. 2013, 368, 1888-1897. DOI: 10.1056/NEJMoa1304459. (c) Le, Q. M.; Kiso, M.; Someya, K.; Sakai, Y. T.; Nguyen, T. H.; Nguyen, K. H.; Pham, N. D.; Ngyen, H. H.; Yamada, S.; Muramoto, Y.; Horimoto, T.; 
Takada, A.; Goto, H.; Suzuki, T.; Suzuki, Y.; Kawaoka, Y. Avian flu: isolation of drugresistant H5N1 virus. Nature 2005, 437, 1108. DOI: 10.1038/4371108a.

3) (a) Skowronski, D. M.; Janjua, N.Z.; De Serres, G.; Sabaiduc, S. ; Eshaghi, A. ; Dickinson, J. ; Fonseca, K. ; Winter, A. ; Gubbay, J. ; Krajden, M. ; Charest, H. ; Bastien, N. ; Kwindt, T. ; Mahmud, S.; Van Caeseele, P.; Li, Y. Low 2012-13 influenza vaccine effectiveness associated with mutation in the egg-adapted H3N2 vaccine strain not antigenic drift in circulating viruses. PLoS One 2014, 9(3), e92153. https://doi.org/10.1371/journal.pone.0092153 (b) Jackson, M. L; Chung, J. R.; Jackson, L. A. Influenza vaccine effectiveness in the United States during the 2015-2016 season. N. Engl. J. Med. 2017, 377, 534-543. DOI: 10.1056/NEJMoa1700153.

4) (a) Yuan, P.; Bartlam, M.; Lou, Z.; Chen, S.; Zhou, J.; He, X.; Lv, Z.; Ge, R.; Li, X.; Deng, T.; Fodor, E.; Rao, Z.; Liu, Y. Crystal structure of an avian influenza polymerase PA(N) reveals an endonuclease active site. Nature 2009, 458, 909-913. (b) Dias, A.; Bouvier, D.; Crépin, T.; McCarthy, A.; Hart, D.; Baudin, F.; Cusack, Stephen; Ruigrok, R. The capsnatching endonuclease of influenza virus polymerase resides in the PA subunit. Nature 2009, 458, 914-918. doi:10.1038/nature07745. (c) Kawaguchi, K.; Uehara, T.; Sato, C.; Hirotsu, N.; Ishida, T.; Watanabe, A. Effects of S-033188, a cap-dependent endonuclease inhibitor, on influenza symptoms and viral titer: Results from a phase 2, randomized, doubleblind, placebo-controlled study in otherwise healthy adults with seasonal influenza. Poster presented at ESWI 2017. (d) Hayden, F.G.; Sugaya, N.; Hirotsu, N.; Lee, N.; de Jong, M.; Hurt, A.; Ishida, T.; Sekino, H.; Yamada, K.; Portsmouth, S.; Kawaguchi, K.; Shishido, T.; Arai, M.; Tsuchiya, K.; Uehara, T.; Watanabe, A. Baloxavir Marboxil for uncomplicated influenza in adults and adolescents. $N$. Engl. J. Med. 2018, 379, 913-923. DOI: 10.1056/NEJMoa1716197

5) Moscona, A. Neuraminidase inhibitors for influenza. N. Engl. J. Med. 2005, 353, 1363-1373. DOI: 10.1056/NEJMra050740

6) (a) Thorland, K.; Awad, T.; Boivin, G.; Thabane, L. Systematic review of influenza resistance to the neuraminidase inhibitors. BMC Infect. Dis. 2011, 11, 134. (b) Le, Q. M.; Kiso, M.; Someya, K.; Sakai, Y. T.; Nguyen, T. H.; Guilligay, D.; Tarendeau, F.; Resa-Infante, P.; Coloma, R.; Crépin, T.; Sehr, P.; Lewis, J.; Ruigrok, R. W.; Ortin, J.; Hart, D. J.; Cusack, S. The structural basis for cap binding by influenza virus polymerase subunit PB2. Nat. Struct. Mol. Biol. 2008, 15, 500-506. DOI: 10.1038/nsmb.1421.

7) Uyeki, T. M. A Step Forward in the Treatment of Influenza. N. Engl. J. Med. 2018, 379, 975977. DOI: 10.1056/NEJMe1810815.

8) Gates, W. Innovation for Pandemics, N. Engl. J. Med. 2018; 378:2057-2060, DOI: 10.1056/NEJMp1806283 
9) Bryn, R.A.; Jones, S. ; Bennett, H. B.; Bral, C.;Clark, M.P.; Jacobs, M.D.; Kwong, A.D.; Ledeboer, M.; Leeman, J.; McNeil, C., Murcko, M.; Nezami, A.; Perola, E.; Rijnbrand, R.; Saxena, K.; Tsai, A.W.; Zhou, Y.; Charifson, P.S. Preclinical activity of VX-787, a first-inclass, orally bioavailable inhibitor of the influenza virus polymerase PB2 subunit Anti. Ag. Chem. 2015, 59, 1569-1582.

10) Clark, M. ; Ledeboer, M.; Davies, I.; Byrn, R. A.; Jones, S. M.; Perola, E.; Tsai, A.; Jacobs, M.; Nti-Addae, K.; Bandarage, U. K.; Boyd, M. J.; Bethiel, R. S.; Court, J. J.; Deng, H.; Duffy, J. P.; Dorsch, W. A.; Farmer, L. J.; Gao, H.; Gu, W.; Jackson, K.; Jacobs, D. H.; Kennedy, J. M.; Ledford, B.; Liang, J.; Maltais, F.; Murcko, M.; Wang, T.; Wannamaker, M. W.; Bennett, H. B.; Leeman, J. R.; McNeil, C.; Taylor, W. P.; Memmott, C.; Jiang, M.; Rijnbrand, R.; Bral, C.; Germann, U.; Nezami, A.; Zhang, Y.; Salituro, F. G.; Bennani, Y. L.; Charifson, P. Discovery of a novel, first-in-class, orally bioavailable azaindole inhibitor (VX-787) of influenza PB2. J. Med. Chem. 2014, 57, 6668-6678.

11) (a) te Velthuis, A.; Fodor, E. Influenza virus RNA polymerase: insights into the mechanisms of viral RNA synthesis. Nat. Rev. Microbiol. 2016, 14, 479-493. (b) Schrauwen, E. J.; de Graaf, M.; Herfst, S.; Rimmelzwaan, G. F.; Osterhaus, A. D.; Fouchier, R. A. Determinants of virulence of influenza A virus. Eu. J. Clin. Microbiol. Infect. Dis. 2014, 33, 479-490.

12) Silverman, R. The organic chemistry of drug design and drug action. Academic Press, San Diego, California, 1992, pp 19-22.

13) For a review see Meanwell, N.A. Synospsis of some recent tactical application of bioisosteres in drug design. J. Med. Chem. 2011, 54, 2529-2591.

14) Boyd, M. ; Bandarage, U. ;Bennett, H. ; Byrn, R. ; Davies, I. ; Gu, W. ; Jacobs, M. ; Ledeboer, M. ; Ledford, B. ; Leeman, J. ; Perola, E. ; Wang, T. ; Bennani, Y. ; Clark, M. ; Charifson, P. Isosteric replacements of the carboxylic acid of drug candidate VX-787: effect of charge on antiviral potency and kinase activity of azaindole-based influenza PB2 inhibitors. Bioorg. Med. Chem. Lett., 2015, 25, 1990-1994. doi.org/10.1016/j.bmcl.2015.03.013.

15) Xiong, J.; Wang, J.; Hu, G.; Zhao, W.; Li, J. Design, synthesis and biological evaluation of novel, orally bioavailable pyrimidine-fused heterocycles as influenza PB2 inhibitors. Eu J. Med. Chem. 2019, 162, 249-265. https://doi.org/10.1016/j.ejmech.2018.11.015.

16) (a) Jones, D.A.; Watkinson, J.G. Infrared studies of the hydrogen bonding of phenolic hydroxyl groups. Part I. Intermolecular bonding to halogen atoms. J. Chem. Soc. 1964, 23662370. (b) Schweitzer, B.A.; Kool, E.T. Hydrophobic, non-hydrogen-bonding bases and base pairs in DNA. J. Amer. Chem. Soc. 1995, 117, 1863-1872. DOI: 10.1021/ja00112a001 (c) Jarchow-Choy, S.K.; Sjuvarsson, E.; Sintim, H.; Eriksson, S.; Kool, E. Nonpolar nucleoside mimics as active substrates for human thymidine kinases. J. Amer. Chem. Soc. 2009, 131, 5488-5494. DOI: $10.1021 /$ ja808244t. 
17) Suydam, I.T.; Strobel, S.A. Fluorine substituted adenosines as probes of nucleobase protonation in functional RNAs. J. Amer. Chem. Soc. 2008, 130, 13639-13648. DOI: 10.1021/ja803336y.

18) Heinrich, T.; Böttcher, H.; Bartoszyk, G.D.; Schwartz, H.; Anzali, S.; Marz, J.; Greiner, H.E.; Seyfried, C.A. Bioisosterism of fluorine and cyano as indole substituents. Theoretical, in vitro and in vivo examination. Chimia 2004, 58, 143-147. DOI: https://doi.org/10.2533/000942904777678118.

19) (a) Vinogradov, S. N.; Linnell, R. H. Hydrogen bonding; Van Nostrand Reinhold Company, New York, 1971, pp 124-135. (b) Dalvit, C.; Invernizzi, C.; Vulpetti, A. Fluorine as a Hydrogen-Bond Acceptor: Experimental Evidence and Computational Calculations. Chem. Eur. J. 2014, 20, 11058 - 11068. (d) Takemura, H.; Kotoku, M.; Yasutake, M.; Shinmyozu, T. 9-Fluoro-18-hydroxy-[3.3]metacyclophane: Synthesis and estimation of a $\mathrm{C}-\mathrm{F} \cdots \mathrm{H}-\mathrm{O}$ hydrogen bond. Eur. J. Org. Chem. 2004, 2019-2024.

20) Hengrung N.; El Omari, K.; Serna Martin, I.; Vreede F.T.; Cusack, S.; Rambo, R.P.; Vonrhein, C.; Bricogne, G.; Stuart, D.I.; Grimes, J.M.; Fodor E. Crystal structure of the RNA-dependent RNA polymerase from influenza $C$ virus. Nature 2015 5, 527, 114-117. doi: 10.1038/nature 15525

21) Ma, X; Xie, L.; Wartchow, C.; Warne, R.; Xu, Y.; Rivkin, A.; Tully, D.; Shia, S.; Uehara, K.; Baldwin, D.; Muiru, G.; Zhong, W.; Zaror, I.; Bussiere, D.; Leonard, V. Structural basis for therapeutic inhibition of influenza A polymerase PB2 subunit. Scientific Reports 2017, 7, Article number: 9385

22) Pflug, A.; Gaudon, S.; Resa-Infante, P.; Lethier, M.; Reich, S.; Schulze, W.M.; Cusack, S. Capped RNA primer binding to influenza polymerase and implications for the mechanism of cap-binding inhibitors. Nucleic Acids Res. 2018, 25, 956-971. doi: 10.1093/nar/gkx1210.

23) Bandarage, U. K.; Clark, M. P.; Perola, E.; Gao, H.; Jacobs, M.D.; Tsai, A.; Gillespie, J.; Kennedy, J. M.; Maltais, F.; Ledeboer, M. W.; Davies, I.; Gu, W.; Byrn, R. A.; Nti Addae, K.; Bennett, H.; Leeman, J.R.; Jones, S. M.; O’Brien, C.; Memmott, C.; Bennani, Y.; Charifson, P.S. Novel 2-substituted 7-azaindole and 7-azaindazole analogues as potential antiviral agents for the treatment of influenza. ACS Med.Chem. Lett. 2017, 8, 261-265.

24) Vonrhein, C.; Flensburg, C.; Keller, P.; Sharff, A.; Smart, O.; Paciorek, W.; Womack, T.; Bricogne, G. Data processing and analysis with the autoPROC toolbox. Acta Cryst. 2011, D67, 293-302.

25) McCoy, A.J.; Grosse-Kunstleve, R.W.; Adams, P.D.; Winn, M.D.; Storoni, L.C.; Read, R.J. Phaser crystallographic software. J. Appl. Crystallogr. 2007, 40, 658-674. 
26) Emsley, P.; Lohkamp, B.; Scott, W.G.; Cowtan, K. Features and development of Coot. Acta Cryst. 2010, D66, 486-501. doi:10.1107/S0907444910007493

27) Afonine, P.V.; Grosse-Kunstleve, R.W.; Echols, N.; Headd, J.J.; Moriarty, N.W.; Mustyakimov, M.; Terwilliger, T.C.; Urzhumtsev, A.; Zwart, P.H.; Adams, P.D. Towards automated crystallographic structure refinement with phenix.refine. Acta Cryst. 2012, D68, 352-67. doi.org/10.1107/S0907444912001308

28) Schüttelkopf, A. W.; van Aalten, D. M. PRODRG: a tool for high-throughput crystallography of protein-ligand complexes. Acta Cryst. 2004, D60, 1355-1363. doi.org/10.1107/S0907444904011679. 